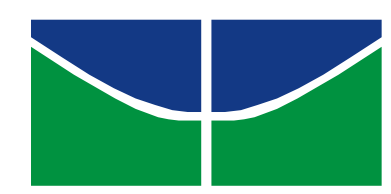

Universidade de Brasília

Centro de Excelência em Turismo

Pós-graduação Lato Sensu

Curso de Especialização em Tecnologia de Alimentos

\title{
DO MILHO À PAMONHA
}

Potira Morena Souza Benko de Uru

Orientadora: Ms. Rita de Cássia Akutsu

Brasília - 2007 


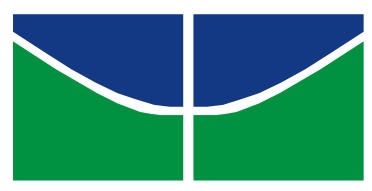

Universidade de Brasília

Centro de Excelência em Turismo

Pós-graduação Lato Sensu

Curso de Especialização em Tecnologia de Alimentos

\title{
DO MILHO À PAMONHA
}

\author{
Potira Morena Souza Benko de Uru
}

Orientadora: Ms.Rita de Cássia Akutsu

Monografia apresentada ao Centro de Excelência em Turismo da Universidade de Brasília como requisito parcial para a obtenção do certificado de Especialista em Tecnologia de Alimentos.

Brasília - 2007 


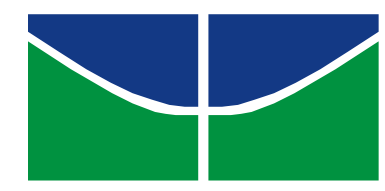

Universidade de Brasília

Centro de Excelência em Turismo

Pós-graduação Lato Sensu

Curso de Especialização em Tecnologia de Alimentos

\section{Potira Morena Souza Benko de Uru}

Aprovado por:

$\overline{\text { Profa. Ms. Rita de Cássia Akutsu }}$

Orientadora

Profa. Dra . Raquel Braz Assunção Botelho

Profa $^{a}$. Dra ${ }^{a}$ Karin Eleonora Sávio de Oliveira

Brasília, 06 de março de 2007 
Uru, Potira Morena Souza Benko de.

Do Milho à Pamonha / Potira Morena Souza Benko de Uru.

$60 \mathrm{f}$.

Monografia (especialização) - Universidade de Brasília, Centro de

Excelência em Turismo, 2007.

Orientadora: Rita de Cássia Akutsu.

1. Milho. 2. Pamonha. 3. Cultura 


\section{DEDICATÓRIA}

Aos meus grandes mestres na vida e incentivadores do desafio de aprender: meus pais, Divina Maria e João Benko Neto.

Ao meu amado Marcelo pela cumplicidade e aos nossos pimpolhos (Mateus e Carol Morena) por entenderem que a mamãe tinha que estudar. 


\section{AGRADECIMENTOS}

À querida parceira neste desafio, minha orientadora Rita Akutsu;

À empresa JERIVÁ;

Ao professor Luiz Antonio Borgo e à equipe do laboratório de Agronomia; Ao pessoal da biblioteca do CET;

A Marianna pelas correções;

A empresa BIOMATRIX;

Aos meus irmãos João e Fernando pelos ajustes gráficos. 


\section{RESUMO}

Os alimentos garantem vida aos seres humanos. Foram introduzidos na realidade humana desde nossos ancestrais, provavelmente, a partir da observação dos animais na natureza. Sendo como um só, alimento e ser humano escrevem juntos a história da vida, em que a cultura dos povos está escrita na alimentação. Assim, resgatar a história de um produto é permitir a valorização da cultura. O milho é considerado o primeiro cereal brasileiro, que, por características de produção, só nasce se for semeado. Isto significa que, para ter sido espalhado pelo mundo, teve a mão humana para realizar tal trabalho. Um dos derivados do milho que representa uma herança cultural de confraternização é a pamonha, que foi herdada dos índios, posteriormente aperfeiçoada tanto por portugueses quanto por africanos. Embora consumida em muitas regiões brasileiras, não há um consenso em qual estado a pamonha é tida como prato típico. Surge, assim, o desafio de estudar melhor o produto pamonha resgatando sua história, o que engloba estudar a história da alimentação, bem como a do milho, seu ingrediente básico. Ao final de uma viagem tão "gostosa", fica a certeza da necessidade de resgatar a cultura alimentar do povo brasileiro, a fim de que a mesma seja cuidadosamente adaptada em prol dos princípios de uma alimentação saudável.

Palavras-chave: pamonha, milho, cultura, comida típica. 


\begin{abstract}
Food guarantees human life. It had been introduced to human reality since the beginning of time, probably trough the observation of animals feeding themselves. As if they where the same thing, food and human beings write together the history of life. Also, different cultures can be described by there relations with nutriment. Thus, to tell the history of a aliment is also to rise the culture in value. The corn is considered the first Brazilian cereal. Given its nature, only the regular sowing seeds can grow crops. It means for sure that the human beings where directly responsible for its spreading around the world. One of the products that come from the corn is the pamonha (a sweet made of corn), which represents a cultural inheritance. It was first introduced by the Indians, and then changed by the Portuguese and by the African descendents. Although it is consumed in many Brazilian regions, it is not decided in which state it is considered a typical dish. So it rises the challenge of studding the pamonha, which goes trough the study of food and also trough the history of corn. In the end of this so delicious trip, it remains the certainty that it is necessary to study the food habits of Brazilian people, with the aim of making it a healthful feeding.
\end{abstract}

Key words: pamonha, corn, culture, typical food. 


\section{LISTA DE FIGURAS}

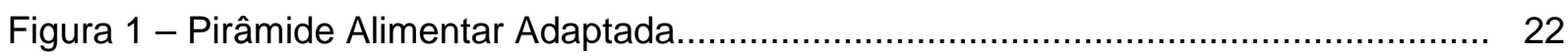

Figura 2 - Amostras Arqueológicas de Milho............................................................. 25

Figura 3 - Milho no Ponto de Colheita para Pamonha................................................ 45

Figura 4 - Pamonha Pronta para Consumo .............................................................. 46

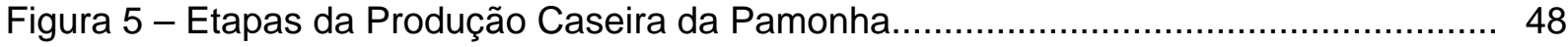




\section{LISTA DE TABELAS}

Tabela 1 - Destino da Produção de Milho em Grãos.

28

Tabela 2 - Composição nutricional de grãos e cereais

Tabela 3 - Resultado de Análises Laboratoriais pela UnB - Amostras de Milho. 30

Tabela 4 - Exemplos da Utilização de Milho em Diferentes Segmentos - Brasil. 31

Tabela 5 - Estimativa de Consumo de Milho por Setor no Brasil. 33

Tabela 6 - Percentual de amilose e intervalo de gelificação dos amidos 35

Tabela 7 - Solubilidade da Amilose e Amilopectina em Água 35

Tabela 8 - Características físicas e físico-químicas da pamonha durante período de comercialização.

Tabela 9 - Resultado de Análises Laboratoriais pela UnB - Amostras de Pamonhas pasteurizadas (crua) congeladas 
SUMÁRIO

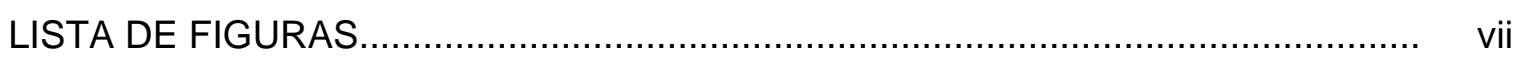

LISTA DE TABELAS...................................................................................... viii

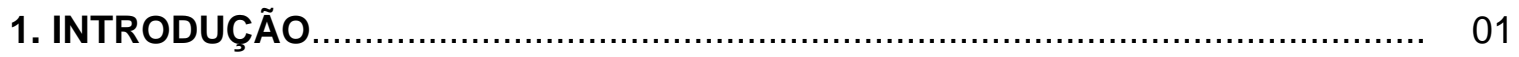

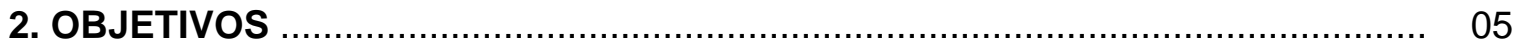

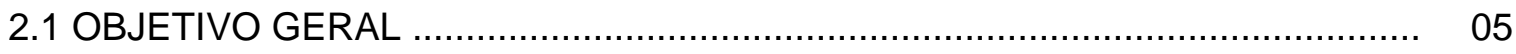

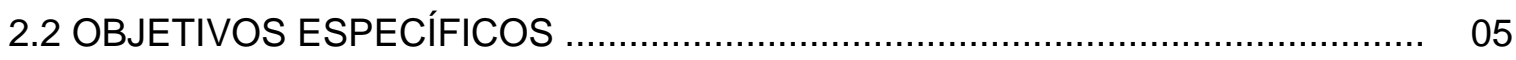

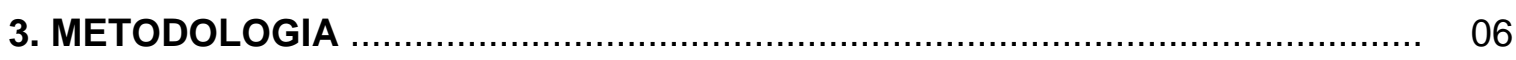

4. CAPÍTULO 1 - HISTÓRIA DA ALIMENTAÇÃO............................................ 08

4.1 ALIMENTAÇÃO NA PRÉ-HISTÓRIA.......................................................... 09

4.2 HERANÇA INDÍGENA NA ALIMENTAÇÃO ............................................... 11

4.3 CONTRIBUIÇÃO PORTUGUESA NA ALIMENTAÇÃO................................... 13

4.4 CONTRIBUIÇÃO AFRICANA NA CULINÁRIA ........................................... 14

5. CAPÍTULO 2 - ALIMENTAÇÃO E CULTURA …............................................. 16

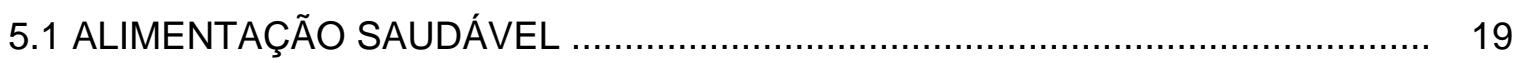

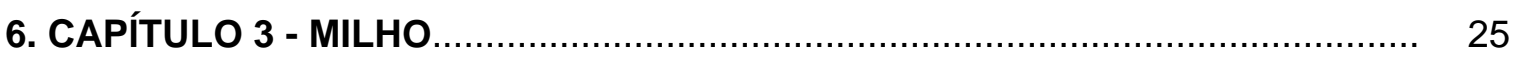

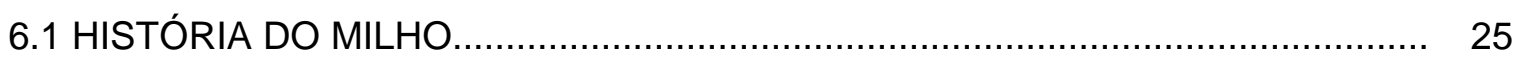

6.2 USO DO MILHO NA CULINÁRIA .......................................................... 30

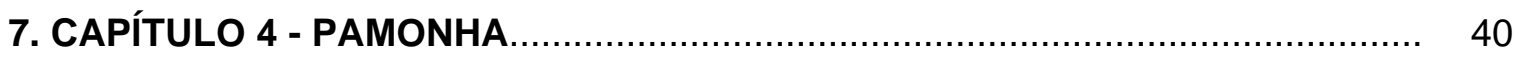

7.1 HISTÓRIA DA PAMONHA ...................................................................... 40

7.2 RECEITAS E PROCESSAMENTO DA PAMONHA...................................... 43

8. CAPÍTULO 5 - CONCLUSÃO E DISCUSSÃO.................................................. 52

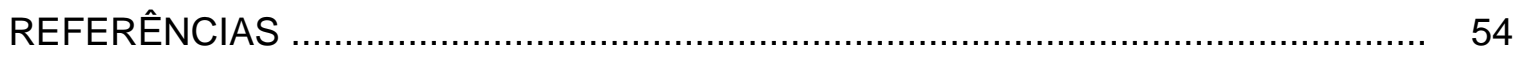

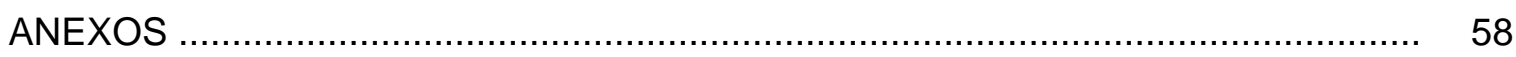

ANEXO 1 - FICHA DE PREPARAÇÃO DA PAMONHA "DE DOCE" ........................ 59

ANEXO 2 - FICHA DE PREPARAÇÃO DA PAMONHA "DE SAL" ............................ 60 


\section{INTRODUÇÃO}

Alimentar-se vai além das necessidades fisiológicas humanas. É um ato que carrega consigo culturas milenares e simboliza organização, crítica familiar, alegrias, dissabores, novidades. "Come-se conforme as normas da sociedade" (ARAÚJO et al., 2005, p. 13). É neste sentido que Botelho revela que "Mais que uma necessidade de sobrevivência, a alimentação distingue culturas" (2006, p. viii).

Numa viagem ao passado, inspirados pelo livro de Luís da Câmara Cascudo (2004), reafirma-se que os seres humanos evoluíram da vida nômade, na qual a oferta de alimento determinava o destino para onde ir. Assim, o ser humano aprende a cultivar seus alimentos e criar seus animais. Nessa busca pelo alimento que mantém a vida, foram acumuladas informações acerca do clima, da vegetação e do melhor lugar e da melhor maneira para o cultivo. Acrescido a isso, tem-se uma troca de informações a partir das conquistas de territórios, onde civilizações, embora fossem dominadas, conseguiam trocar conhecimento sobre alimentação, uma vez que era essencial para a sobrevivência em regiões desconhecidas.

Então, a população brasileira carrega hábitos alimentares que foram passados de geração em geração e que refletem a história de cada região. $\mathrm{Na}$ culinária brasileira, pode-se encontrar a presença tanto de índios, portugueses e africanos quanto de imigrantes de países diversos (GINANI, 2004). Daí, resulta-se na mesa como uma obra de arte; uma explosão de cores, sabores, história e 
temperos (FERNANDES, 2004). Influenciados por todos os povos, por todos os costumes do mundo, somos um país (FISBERG et al., 2002).

Considerar a gastronomia como representante da cultura de um povo ficou evidenciado nos esforços de Ana Claudia Lima e Alves, gerente de Registro do Departamento do Patrimônio Imaterial do Iphan (Instituto do Patrimônio Histórico e Artístico Nacional). Embora exista desde 1937, somente a partir de 2000 é que o Iphan aceitou que o conceito de "patrimônio cultural" passasse a ser reconhecido oficialmente pela instituição como algo que vai além de monumentos, sítios e bens móveis do país (ACS- ASSESSORIA DE COMUNICAÇÃO SOCIAL DA UnB, 2005). Com isso, passou-se a ter incluído na lista de bens culturais de natureza imaterial as técnicas culinárias e todas as relações sociais advindas da prática gastronômica.

Resgatar hábitos alimentares de uma região torna-se uma ação importante na preservação da cultura de um povo (FERNANDES, 2004). O reconhecimento de características próprias, presentes nas preparações culinárias, por membros de uma sociedade, desperta o sentido de pertencer de cada indivíduo (BOTELHO, 2006).

Em outra direção e, com o objetivo de incentivar a alimentação saudável, 0 Ministério da Saúde lançou livros e artigos com receitas de alimentos de origem vegetal de custo acessível e alto valor nutritivo (MINISTÉRIO DA SAÚDE, 2004; BRASIL, 2002) o que de certa forma contribui para o resgate da alimentação saudável enquanto patrimônio cultural.

Entre os produtos considerados regionais da culinária brasileira, tem-se a pamonha como um derivado do milho, que, por ser um produto originalmente cozido, mas feito com gordura animal (banha de porco), permite estudos para substituição de ingredientes para garantir que seja mais nutritivo e saudável. Assim, é possível colocar em prática a conclusão da dissertação da pesquisadora Verônica Cortez Ginani (2004, p. 10), que afirma que "o respeito por hábitos alimentares, mesmo diante das necessidades de restrições nutricionais, é viável quando técnicas de cocção e ingredientes são utilizados de forma adequada". 
Com a finalidade de resgatar informações sobre a culinária brasileira, foi escolhido o produto do milho mais comumente consumido na região: a pamonha. Este produto simboliza uma parte da cultura voltada para os encontros de famílias e remete à vida da roça. As pamonhadas que reuniam toda a família e vizinhança e levavam o dia todo, iniciando com a colheita do milho, passando por descascar, selecionar a palha, ralar milho, temperar a massa, amarrar as pamonhas, cozinhar nos grandes panelões sobre o fogão à lenha até o consumo, regados a boa música e bebida.

A pamonha é um produto vinculado a festas, reuniões familiares, o que reforça sua representatividade da cultura brasileira. Neste estudo, foi feita uma busca pela origem tanto da pamonha quanto do seu principal ingrediente, que é o milho. Relataram-se informações acerca da história do milho e da pamonha bem como as variações de receitas encontradas nas diferentes bibliografias. Seguiu-se no relato de informações nutricionais tanto de tabelas de composição de alimentos quanto de análises feitas em laboratório. Os resultados bibliográficos obtidos reforçaram o que a pesquisadora Raquel Botelho (2006) afirma em sua tese: a necessidade de trabalhos que avaliem as preparações regionais e a determinação da composição nutricional das mesmas.

Tem-se no milho, segundo Udry et al. (2000), uma das espécies cultivadas em praticamente todos os continentes. Assim, resgatar e melhorar a qualidade organoléptica da pamonha é uma forma de aproveitar uma matéria-prima difundida e ao mesmo tempo ter a possibilidade de divulgar uma iguaria regional.

Para uma melhor compreensão, o presente estudo foi dividido em cinco capítulos: No primeiro capítulo foi realizada uma revisão da história da alimentação, a contribuição da herança cultural indígena, portuguesa e africana sobre a alimentação brasileira. No segundo capítulo, recupera-se a interface da alimentação saudável da perspectiva cultural. No terceiro capítulo, descreve-se a história do milho, seguida da revisão das formas de cultivo, envolvendo então a questão do milho híbrido, especificando qual a variedade mais usada para fazer pamonha. Seguiu-se com um levantamento bibliográfico da composição nutricional do milho. 
No quarto capítulo foi realizado o resgate de relatos bibliográficos acerca da origem e representatividade da pamonha como comida típica. No quinto e último capítulo, tratou-se de apontar em síntese os achados acerca da pamonha e apontar para a necessidade de novos estudos não só acerca da pamonha como de outros produtos típicos da culinária brasileira. 


\section{OBJETIVOS}

\subsection{OBJETIVO GERAL}

Resgatar informações acerca do produto pamonha desde sua origem até as pesquisas mais recentes acerca de sua matéria-prima, que é o milho.

\subsection{OBJETIVOS ESPECÍFICOS}

- Estudar a História da alimentação, desde a pré-história, passando depois pelas contribuições de portugueses e africanos;

- Relacionar a cultura alimentar e a alimentação saudável;

- Investigar a história do milho e da pamonha, bem como o uso dos mesmos na culinária;

- Buscar embasamento para evidenciar a origem da pamonha e de qual Estado brasileiro ela é tida como prato-típico. 


\section{METODOLOGIA}

Para o presente estudo foi adotada uma metodologia exploratória por documentação indireta que servirá de ponto de partida para trabalhos futuros com estudos empíricos. Em virtude do berço da matéria-prima da pamonha, o milho, está na América Central, especificamente no México, realizam-se estudos nas línguas portuguesa e espanhola.

Pretende-se com esta revisão somar esforços ao trabalho de Silva et al. (2003), Ginani (2004) e Botelho (2006), que tratam de pratos típicos da perspectiva da alimentação saudável além de realizarem uma análise cultural dos mesmos. Cabe destacar que o trabalho desses pesquisadores é parte de uma tendência de tratar o resgate da alimentação do ponto de vista nutricional, antropológico e sociológico.

Foi realizada pesquisa bibliográfica na base de dados Scielo no período de 1990 a 2006 em português e espanhol, na qual buscou-se resgatar o máximo de trabalhos específicos envolvendo pamonha a fim de que se pudesse definir sua origem em termos de povos e região bem como em qual região brasileira ela é tida como prato típico.

A escassez de material bibliográfico para o produto pamonha fez com que 0 trabalho fosse analisado da perspectiva histórica, cultural e nutricional do seu principal componente - o milho, o que possibilitou uma visão panorâmica do tema. 
Portanto, o presente trabalho reforça a necessidade de estudos que resgatem a culinária regional e que procurem o melhoramento nutricional das preparações regionais para se ter uma alimentação saudável. 


\section{CAPÍTULO 1- HISTÓRIA DA ALIMENTAÇÃO}

Em seu trabalho, Gomensoro (1999) trata da evolução da história da gastronomia desde as conquistas territoriais que abriram o paladar, passando pelas guerras que trouxeram o desenvolvimento tecnológico até reafirmar a teoria de que numa cozinha tudo se transforma.

A evolução do ser humano acontece em conjunto com o desenrolar da história de tal maneira que, segundo trabalho desenvolvido pelo Departamento de Nutrição na Faculdade de Saúde da Universidade de Brasília para o Ministério da Saúde (2004), evoluiu-se da vida nômade para o que hoje se tem de mais especializado, que é uma ciência própria da alimentação: que é a Nutrição. Assim, resgataram-se informações acerca da história da alimentação humana desde o momento em que o homem passou a alimentar-se de frutos e raízes, observando o comportamento de outros animais.

Neste contexto, citam-se Botelho (2006), Cascudo (2004), Fernandes (2004), Fisberg (2002), Freyre (1980), Ginani (2004) e Ortencio (2000) que falam da história da alimentação resgatando informações desde a pré-história até os dias de hoje.

Os estudos citados dão uma noção do crescente interesse da sociedade e de ciências como: Nutrição, Antropologia, Sociologia, Filosofia e História entre outras acerca do alimento, da alimentação e da sua influência na evolução das sociedades humanas. Comprovando assim a inter-relação do desenvolvimento histórico em conjunto com a alimentação. 
Alimentar-se não significa um ato para suprir apenas necessidades fisiológicas. Carrega consigo toda a cultura de um povo, fato este que fica claro quando se estuda as contribuições dos povos formadores do povo brasileiro, como índios, portugueses e africanos.

\subsection{ALIMENTAÇÃO NA PRÉ-HISTÓRIA}

Evoluindo com a observação tanto dos animais quanto da natureza, o ser humano escreveu sua história com as próprias mãos, principalmente através de hábitos alimentares, os quais foram sendo incorporados e até compartilhados com outros povos.

Com vistas à compreensão da evolução da alimentação desde a pré-história, várias instituições ao redor do mundo vêem desenvolvendo pesquisas em diversas áreas. No trabalho desenvolvido pela Universidade de Brasília (MINISTÉRIO DA SAÚDE, 2004), relata-se que as frutas eram o cardápio original do ser humano. Evoluiu-se depois para o acréscimo das raízes no cardápio, provavelmente oriundas do trabalho feminino, já que a caça e a pesca ficavam a cargo dos homens. Essas informações foram confirmadas por estudos arqueológicos que traziam indícios de uso do fogo e de ferramentas de pedra e/ou de madeira e ossos, que auxiliavam na caça e no consumo das mesmas. Como ainda não havia conhecimento, prática da agricultura nem mesmo a domesticação de animais, no período conhecido como Paleolítico (500.000 a.C. a 1.000 a.C.), o ser humano vivia como nômade.

Ginani (2004) também compartilha dessas informações e mostra em seu trabalho a evolução da postura física ereta do ser humano atuando nas suas conquistas de caças maiores. Ainda, a descoberta do fogo propiciou melhorias na forma de preparo e conservação dos alimentos, como, por exemplo, o ato de enterrar carnes em cinzas quentes ou secá-las ao ar livre. 
Nesse processo de vida nômade, foi sendo percebido pelo ser humano que as sementes que caíam sobre a terra multiplicavam suas colheitas em pouco tempo (cerca de meses). Este fato sinalizou o início da agricultura, em que se trocou a vida nômade pela vida em aldeias.

Já no período Neolítico (10.000 a.C. a 4.000 a.C.), houve o desenvolvimento da agricultura e a criação de animais, que permitiam uma maior ação do homem sobre a natureza. Com isso, houve colheitas mais fartas, possibilitando o crescimento da população. Assim, formaram-se as tribos, que eram grupos familiares maiores. Neste período, também chamado de Idade dos Metais, começou efetivamente a base da alimentação humana, caracterizada pela cultura de cereais (trigo e centeio principalmente) e tornou possível a produção artesanal de pães e alimentos líquidos.

Evidências fortes quanto à história da alimentação são fornecidas pelo Antigo Egito, onde estudos arqueológicos nas tumbas mostram os alimentos consumidos pelos faraós, tais como: massas, carnes, peixes, laticínios, frutas, hortaliças, cereais, condimentos, especiarias, mel e bebidas. Caracteriza-se, assim, o uso de cereais como trigo, milho, arroz e cevada desde os povos antigos. Conhecia-se também a ação terapêutica da alimentação, relatada nos textos de Hipócrates.

Os períodos históricos que se seguem (Idade Média, Idade Moderna e Idade Contemporânea) são marcados por melhoramentos na alimentação oriundos de observações e interações de povos. Desta maneira, tem-se as seguintes caracterizações dos períodos citados: Idade Média (séculos X a XV d.C.) caracterizada por sabores diferentes como o forte (pela presença dos temperos, também chamados de especiarias); o sabor doce (pelo uso do açúcar) e o ácido (pela atuação de vinagre, vinho e sucos cítricos). Na Idade Moderna (séculos XV a XVIII d.C.), a agricultura passa do objetivo de subsistência para o comercial, tendo importância alimentos como o tomate, a batata, o milho, o arroz entre outros.

Em relatos da Idade Contemporânea (séculos XIX a XX d.C.), está a evolução da alimentação até se chegar na sua designação como gastronomia. A agricultura e a criação de animais continuaram evoluindo no caráter comercial, permitindo assim o 
aumento de variedades de alimentos bem como a difusão, nas demais classes sociais, de produtos, como o açúcar, originalmente consumido pela elite.

Nos relatos de Ginani (2004), reforça-se a evolução da história da alimentação a partir da $1^{\mathrm{a}}$ Guerra Mundial. Ocorreu a partir daquele momento o desenvolvimento de técnicas e utensílios de uso e conservação na alimentação, tais como o fogão, a geladeira, o forno, a conservação de alimentos em vidros, e, posteriormente, em latas.

Atualmente, chegou-se, segundo Ginani (2004), a um ponto da evolução alimentícia em que se pode contar com técnicas de conservação tão apuradas que até começam com ações na genética dos alimentos. Somado a isto, há uma gama muito grande de alimentos ofertados de diferentes nacionalidades, o que foi proporcionado pela globalização.

Embora haja uma grande oferta de produtos alimentícios variados, eles não estão isentos de suas heranças e características culturais. E, em se falando da culinária brasileira, torna-se necessário discorrer sobre as influências de índios, portugueses e negros.

\subsection{HERANÇA INDÍGENA NA ALIMENTAÇÃO}

Segundo Cascudo (2004), há na carta de Pero Vaz de Caminha (escrivão da frota de Cabral), escrita no período do descobrimento do Brasil, o primeiro depoimento sobre a alimentação indígena. No estudo de Freyre (1980), fica clara a influência dos índios na alimentação atual da população brasileira, colocando-os no patamar de formação da família brasileira. Mas, segundo Fernandes (2004), torna-se difícil resumir a atuação indígena na alimentação brasileira, uma vez que, por volta de 1650, somente na Amazônia, existiam cerca de seiscentas nações com grande diversidade de culturas, tipos raciais e línguas. 
Embora com dificuldade, os estudos têm mostrado que o ponto de maior resistência perante às entradas dos portugueses em território brasileiro foi a herança culinária. A mandioca ficou caracterizada como a referência do complexo indígena (FREYRE, 1980). Com a mandioca, a índia ensinou a fazer as farinhas, os mingaus, o beiju, bolos, etc. Mesmo durante a vida nômade e posteriormente com as invasões portuguesas, todo excedente de mandioca era transformado em farinha. Daí ser o único alimento encontrado em quantidade quando da época dos portugueses (FERNANDES, 2004).

Em relação às comidas indígenas, segundo Freyre (1980) e Fernandes (2004), a Amazônia é a área brasileira mais rica de influência indígena. Os pescados caracterizaram-se como o segundo alimento básico dos índios. Como ficava a cargo dos homens assar e das mulheres, cozinhar, inventaram cerâmica, vasilhas, panelas de barro, pratos, etc. No entanto, os alimentos essenciais aos índios eram originários da terra (como raízes, folhas, vegetais e frutos - jabuticaba, caju, cajá, goiaba, maracujá, mamão, laranja, limão, entre outros) e dos animais (como a caça, a pesca e até o uso de mel de abelha).

Como temperos, eram usados sal, pimentas coloridas, limão e gengibre. O sal era proveniente da vegetação após a queima de troncos e posterior fervura das cinzas; as pimentas eram nativas e davam sabor e cheiro aos peixes e mariscos (FERNANDES, 2004). O paladar pela pimenta foi reforçado posteriormente com a chegada do africano, que tinha preferência maior pela pimenta do que o índio (FREYRE, 1980). Também eram feitas bebidas fermentadas a partir do processo de mastigação, que era executado pelas mulheres das tribos a partir de variados alimentos, tais como mandioca, pupunha, milho, cacau, cupuaçu, açaí, caju, buriti, entre outros. Havia também o uso do guaraná na forma de bebida usada para dar disposição antes das caçadas.

Os estudos de Freyre (1980) e Cascudo (2004) indicam a fartura de frutas, mas pouca opção de hortaliças (normalmente havia o caruru, a serralha e o palmito). Também mencionam o milho como o único cereal encontrado pelos europeus no Brasil, do qual eram feitas farinhas,canjica, pamonha (envolvida na própria palha do milho), pipoca e bebidas fermentadas. 
Além de servirem como comida, os variados alimentos indígenas também eram usados como fármacos juntamente com tantas outras plantas e ervas medicinais, as quais têm seu uso terapêutico originário dos pajés e curandeiros (FREYRE, 1980; CASCUDO, 2004).

\subsection{CONTRIBUIÇÃO PORTUGUESA NA ALIMENTAÇÃO}

Com a chegada dos portugueses no Brasil, teve-se a necessidade de adaptação dos colonizadores à realidade dos nativos, uma vez que muitos produtos não resistiam à viagem até a costa brasileira (CASCUDO, 2004). Mesmo assim, a contribuição dos colonizadores na culinária brasileira vai desde a introdução de novos alimentos até à melhoria de receitas e técnicas de produção das variadas comidas. Eram nas cozinhas que as três principais origens da cultura brasileira se juntavam, fazendo com que índios, portugueses e africanos formassem a cultura brasileira (CASCUDO, 2004).

Embora os estudos não consigam precisar exatamente quando começou a culinária brasileira propriamente dita, têm-se contribuições portuguesas que atualmente são inerentes ao Brasil, como, por exemplo: gado, cereais, trigo, aves, couve, alface, pepino, ervilha, abóbora, lentilha, alho, cebola, etc. No entanto, o português deslocou a base de sua alimentação do trigo para a mandioca assim como teve que fazer adaptações no seu sistema de lavoura devido às diferenças de clima e solo (FREYRE, 1980).

No início da colonização, havia fartura de comida, mas que foi substituída por restrições, uma vez que a monocultura da cana de açúcar passou a ser o centro da agricultura do colonizador. Juntamente com as restrições, houve o aumento da população e a migração dos bandeirantes à procura de ouro, sendo que a preferência era pelo garimpo, e não pela agricultura. Assim, aconteceu um período de fome, mas que não apagou a contribuição portuguesa em solo brasileiro (CASCUDO, 2004). 
Um dos hábitos alimentares do colono desconhecido pelo nativo era 0 consumo de galinha e gado até mesmo no caso do gado assado inteiro na brasa. Além disso, havia a contribuição portuguesa trazida de colonizações em outras regiões, tais como uva, figo, maçã, marmelo, pêssego, romã, melão, melancia, etc.

No texto desenvolvido pelo Departamento de Nutrição na Faculdade de Saúde da Universidade de Brasília para o Ministério da Saúde (2004), são relatados o coqueiro, o arroz, o pepino, a mostarda, entre outros, que foram plantados pelos portugueses. No entanto, a maior contribuição portuguesa na culinária brasileira foi o uso do açúcar, que permitiu a partir daí a produção de doces de ovos e de várias frutas (surge assim a goiabada, marmelada, cajuada, etc.) bem como a fabricação da cachaça.

Nos relatos de Cascudo (2004) e Freyre (1980), é mostrada a grande influência da igreja portuguesa tanto sobre a gastronomia brasileira quanto na cultura.Dessa maneira, culmina na junção dessas duas vertentes nas festas tradicionais, como Páscoa, São João e Natal. Embora fossem festas de cunho religioso, mostravam as variadas iguarias da culinária, com o uso da fritura, que era própria dos portugueses.

\subsection{CONTRIBUIÇÃO AFRICANA NA ALIMENTAÇÃO}

Freyre (1980) caracteriza três centros (Bahia, Maranhão e Pernambuco) como concentradores da contribuição africana na alimentação brasileira. O negro já tinha contato com alguns itens da alimentação brasileira, pois os portugueses se incumbiram de difundir alguns alimentos, como farinhas, café, açúcar, cacau. Já o negro, fez algumas adaptações: consumir o milho cozido ou em forma de papa, angu ou fervido com leite de vaca.

Uma cultura importante herdada dos africanos foi o cultivo da bananeira em meados do século XVI assim como da palmeira do dendê, da qual era extraído o azeite de dendê, tão marcante na culinária africana e incorporada no território 
brasileiro. Foram adicionados às essencialidades da culinária africana ingredientes dos índios e portugueses, adaptados conforme a necessidade do escravo em aproveitar as sobras que Ihe eram oferecidas, como é o caso da feijoada (CASCUDO, 2004).

Veio para o Brasil, junto com os negros, a pimenta malagueta (cujo nome localizava a origem), que aumentou ainda mais a afinidade do índio pelo sabor picante. Outros cultivares foram também trazidos pelo negro no decorrer das idas e vindas ao Brasil, tais como quiabo, caruru, inhame, erva-doce, açafrão, gergelim, melancia, etc. Já em relação ao consumo de animais, o que se firmou em território brasileiro foi a galinha-d'angola (FERNANDES, 2004).

Um ponto convergente sobre a história da pamonha pode ser confirmado na página 454 do livro Casa-Grande e Senzala (FREYRE, 1980), no qual é relatada a participação das senhoras das casas-grandes no comércio de doces e quitutes, sendo que alguns quitutes à venda eram feitos nas ruas pelas negras, como mocotó, vatapá, mingaus, pamonhas, angus, pão-de-ló, etc. Esse fato também é reforçado por Fernandes (2004), que relata que os alimentos basicamente indígenas ou da doceria portuguesa eram acompanhados por pratos africanos, tais como acarajé, vatapá, abará, entre outros.

Concentraram-se, então, heranças indígenas, portuguesas e africanas na formação inicial da gastronomia brasileira, permitindo hoje em dia a presença de pratos variados nas diferentes regiões brasileiras conforme explanado no próximo capítulo. 


\section{CAPÍTULO 2 - ALIMENTAÇÃO E CULTURA}

Quando se fala em alimentação, segundo Araújo et al. (2005) há uma revelação de origens, civilidade, comportamentos, culturas. Com cada povo sendo definido por práticas alimentares próprias. Assim, falar de um produto alimentício significa analisar também a cultura pertinente ao mesmo.

"Os alimentos representam a ligação mais primitiva entre natureza e cultura" (FISCHLER, 1988 apud BOTELHO, 2006), pois o ato de comer está associado à cultura e, principalmente, à religião, à moral e à saúde. Também segundo Botelho (2006), são componentes determinantes dos hábitos alimentares os seguintes pontos: fatores econômicos, sociais, políticos, agrários e religiosos.

As influências sobre a cultura compreendem inicialmente os caminhos históricos seguidos por cada nação. Caminhos estes categorizados tanto por questões físicas e ambientais quanto pela interação entre as pessoas. Demonstra-se assim que além de um alimento variar de uma cultura a outra, o mesmo poderá ter características específicas em suas formas de cultivo, colheita, preparo, serviço e ingestão (ARAÚJO et al., 2005).

Em termos de estudos históricos a civilização mais antiga, a egípcia, através de arquivos e até escavações arqueológicas, já demonstra o quanto alimentação e cultura caminham juntas, uma vez que nas próprias tumbas foram encontrados indicativos de produtos como trigo, cevada, milho, pão, dentre tantos outros. Defende-se então a premissa de que a história do ser humano acontece concomitantemente com a participação dos alimentos (BOTELHO, 2006; ARAÚJO et al., 2005). 
A partir desse princípio, tem-se a evolução histórica do ser humano acontecendo desde a observação dos animais, em sua forma de comer, passando pelas descobertas do fogo, o qual traz o primeiro tempero para a alimentação humana até chegar nas trocas de informações em cada descoberta de territórios. Onde se compartilha dos relatos de Botelho (2006) acerca das civilizações gregas e romanas, as quais ilustram inicialmente a evolução histórica da alimentação, uma vez que observaram que a comida não era somente para satisfazer uma necessidade elementar do corpo, mas também para fazer da refeição um momento de sociabilidade.

Referenciando o texto de Botelho (2006) vê-se que ao longo da história dos povos a alimentação se desenvolveu a ponto de ser caracterizada como ciência: a gastronomia. Onde seu desenrolar recebeu atuação tanto de imperadores quanto de monastérios, até chegar a necessidade de mais ingredientes (especiarias). Fazendo com que, também pelo comércio, fosse iniciada a era das expedições marítimas. Com isso houve uma grande modificação nos hábitos alimentares em todo mundo.

Diante da conquista de novos territórios, interações e trocas alimentares foram sendo feitas tanto em termos de novos alimentos quanto novas técnicas e utensílios de uso na culinária. Chegando ao ponto máximo após a revolução industrial (século XIX) com as invenções como fogão a gás, pasteurização e refrigeração inovando na gastronomia (GINANI, 2004).

Quando se restringi o estudo da história da alimentação para o Brasil, referencia-se Cascudo (2004) na afirmação que a herança dos hábitos alimentares da população brasileira veio de africanos, indígenas e europeus. Foram esses povos que moldaram a culinária brasileira ao longo dos tempos através de trocas de receitas e incorporação de produtos, tais como arroz, melancia, abóbora, gengibre, mostarda, cebola, alho, trazidos pelos portugueses e azeite de dendê, camarão seco, pimenta malagueta, entre outros, trazidos pelos negros.

Mas a contribuição e as trocas culinárias não contaram somente com a integração de índios, negros e portugueses. Após a proclamação da independência 
do Brasil, cresceu a imigração e o comércio internacional com a vinda de italianos, espanhóis e alemães além de asiáticos e africanos (GINANI, 2004).

$\mathrm{Na}$ cultura alimentar brasileira, estão presentes heranças inicialmente de portugueses e africanos, que se integraram com os produtos nativos indígenas. Dessa maneira, foram geradas as particularidades das cozinhas regionais brasileiras também influenciadas por acontecimentos históricos e por todos os demais povos que vieram para o Brasil (como italianos, alemães, japoneses, etc.). Vários produtos caracterizam cada região brasileira e podem ter diferenças conforme as referências usadas. Assim, o consumo de diferentes alimentos e as formas de prepará-los foram modificados ao longo do tempo, o que corrobora a afirmação de Ginani "consumir e preparar alimentos se confundem com a própria história do homem." (GINANI, 2004, p. 7).

Como descrito no capítulo anterior, foram muitas as contribuições de índios, portugueses e africanos na culinária brasileira. E durante todo o período de evolução da alimentação brasileira, algumas contribuições foram incorporadas e caracterizaram a gastronomia do Brasil. Pode-se então resumir as várias contribuições de povos na formação do regionalismo culinário brasileiro denominado de "comida típica" (GINANI, 2004; ARAÚJO et al, 2005):

Região Sudeste: em São Paulo, os pratos mais típicos foram herdados de italianos (macarronadas e pizzas), árabes (quibe), índios e bandeirantes (cuscuz à paulista); já no Rio de Janeiro, tem-se feijoada, herdada dos negros; no Espírito Santo, tem-se o hábito de consumir polenta, vindo dos italianos. Em Minas Gerais, está a tríade dos escravos: feijão, angu e couve.

Região Sul: com heranças européias e indígenas, destacam-se o churrasco e o chimarrão.

Região Nordeste: repleta de heranças tanto dos índios nativos quanto dos negros e dos portugueses, é uma das regiões com mais pratos típicos. Entre eles, o acarajé, a moqueca, o vatapá e muitos outros. 
Região Norte: mantém, até hoje, o mesmo consumo dos índios: peixes de rios, milho, mandioca, cará, entre outros.

Região Centro-Oeste: recebeu influência dos exploradores que passaram ou se instalaram pela região, tendo na sua culinária, elementos de todo o país. Mas os produtos mais consumidos da região são a guariroba, o pequi, a banana-da-terra, peixes e caças.

Diante de tantas contribuições na culinária brasileira, tem-se reforçado 0 mesmo caminho que alimentação e cultura fazem, tornando a especificidade de uma nação o resultado da interação com outros povos.

Mediante a variedade de culturas atuando na gastronomia brasileira, torna-se necessário elucidar que a evolução alimentar trouxe consigo mudanças que nem sempre refletem ponto positivo no que diz respeito à saúde. Como exemplo, referenciamos Botelho (2006), que relata contribuições como o uso indiscriminado de açúcar, frituras, poucas fibras, favorecendo problemas de obesidade, hipertensão, diabetes, dislipidemias, dentre tantos outros males oriundos de hábitos alimentares incorretos.

Nesse sentido, cabe acrescentar que mesmo compreendendo a importância cultural da alimentação não se pode perder de vista que as características da vida moderna impõem preocupações que perpassam a manutenção da saúde. Portanto, torna-se necessário destacar conceitos e atributos da alimentação saudável.

\subsection{ALIMENTAÇÃO SAUDÁVEL}

Após relatar o caminho percorrido pela alimentação ao longo da história, chega-se ao ponto desafiante que a modernidade trouxe: alimentar-se corretamente embora a globalização traga opções variadas em termos de oferta de alimentos. Assim, tem-se que partir do entendimento básico do que vem a ser uma alimentação saudável. 
Referenciando Botelho (2006), entende-se que a alimentação saudável não é só o que nutre o corpo fisiologicamente, mas a quantidade, qualidade, harmonia e adequação de nutrientes. Assim sendo, questões sociais e culturais devem ser respeitadas e acima de tudo resgatadas para que o "de comer" de cada região seja melhorado. Pois os alimentos têm cor, sabor, aroma e textura, os quais estão vinculados às questões culturais, onde seu respeito atualmente passa a ser fonte de interesse das políticas governamentais.

São muitos os instrumentos que no Brasil o Ministério da Saúde vem usado para promover a saúde do povo brasileiro, tais como folder, cursos, publicações e parcerias. Pois a questão de vida saudável passa diretamente pelas ofertas de comida disponíveis no mercado. As quais deveriam ser as primeiras a respeitar as diretrizes de uma alimentação saudável. Fato este que só acontece se o entendimento da cultura do povo brasileiro estiver em conjunto com as melhorias nutricionais necessárias nas preparações oferecidas.

Nesse sentido é importante destacar que os conceitos de Escudero (apud SCHILLING, 1998) estão atuais e tem sido confirmados em diversos estudos. Para que uma alimentação seja considerada saudável, Pedro Escudero (1937) estabeleceu quatro requisitos considerados leis:

1-Lei da quantidade: a alimentação deve fornecer ao indivíduo a quantidade de alimentos necessária ao funcionamento do organismo, preservação da espécie e manutenção da saúde.

2-Lei da qualidade: a alimentação deve fornecer diariamente ao indivíduo a qualidade os de nutrientes necessários ao organismo.

3-Lei da harmonia: o alimento deve fornecer todos os nutrientes em proporções de acordo com a necessidade do indivíduo. Deve haver ainda harmonia entre cores, sabores, odores e textura. 
4-Lei da adequação: a alimentação deve ser adequada ao indivíduo considerando o peso, a altura, a idade, a disponibilidade de alimentos, poder aquisitivo, doenças, gestações, e outros.

A quantidade de alimentos ingeridos - quantidade - deve fornecer todos os nutrientes - qualidade -, que devem guardar uma proporção entre si - harmonia e, além disso, devem adequar-se aos hábitos individuais, situação econômico-social e aspectos de necessidades individuais - adequação.

No trabalho de Evangelista (1998), é reforçada a necessidade de divulgar os conhecimentos sobre alimentação e nutrição, uma vez que se alimentar começa com a escolha de um alimento e termina com a sua absorção pelo intestino. Já a nutrição, é o processo biológico que garante ao indivíduo material necessário para as suas atividades físicas, biológicas e mentais, manutenção de reservas e condições para o indivíduo nascer, viver e reproduzir. Assim, o ser humano, a partir do ato de comer, permite que seu organismo seja nutrido de maneira a garantir a vida.

Um dos guias alimentares mais utilizado atualmente é a Pirâmide Alimentar. A qual tenta esquematizar os preceitos de alimentação saudável, mas sem contemplar uma variedade enorme de preparações típicas brasileira.

Mesmo com a contribuição de Philippi et al. (1999), no trabalho de melhorar a pirâmide alimentar, a partir da elaborada nos Estados Unidos em 1992, a mesma continua não refletindo a realidade brasileira. O que pode ser ilustrado na Figura 1, a seguir, uma vez que alimentos regionais (como o acarajé, a pamonha, o cuscuz, etc.) não são contemplados, nem mesmo na Pirâmide Alimentar Adaptada. 
Figura 1 - Pirâmide Alimentar Adaptada

PIRÁMIDE ALMMENTAR ADAPTADA

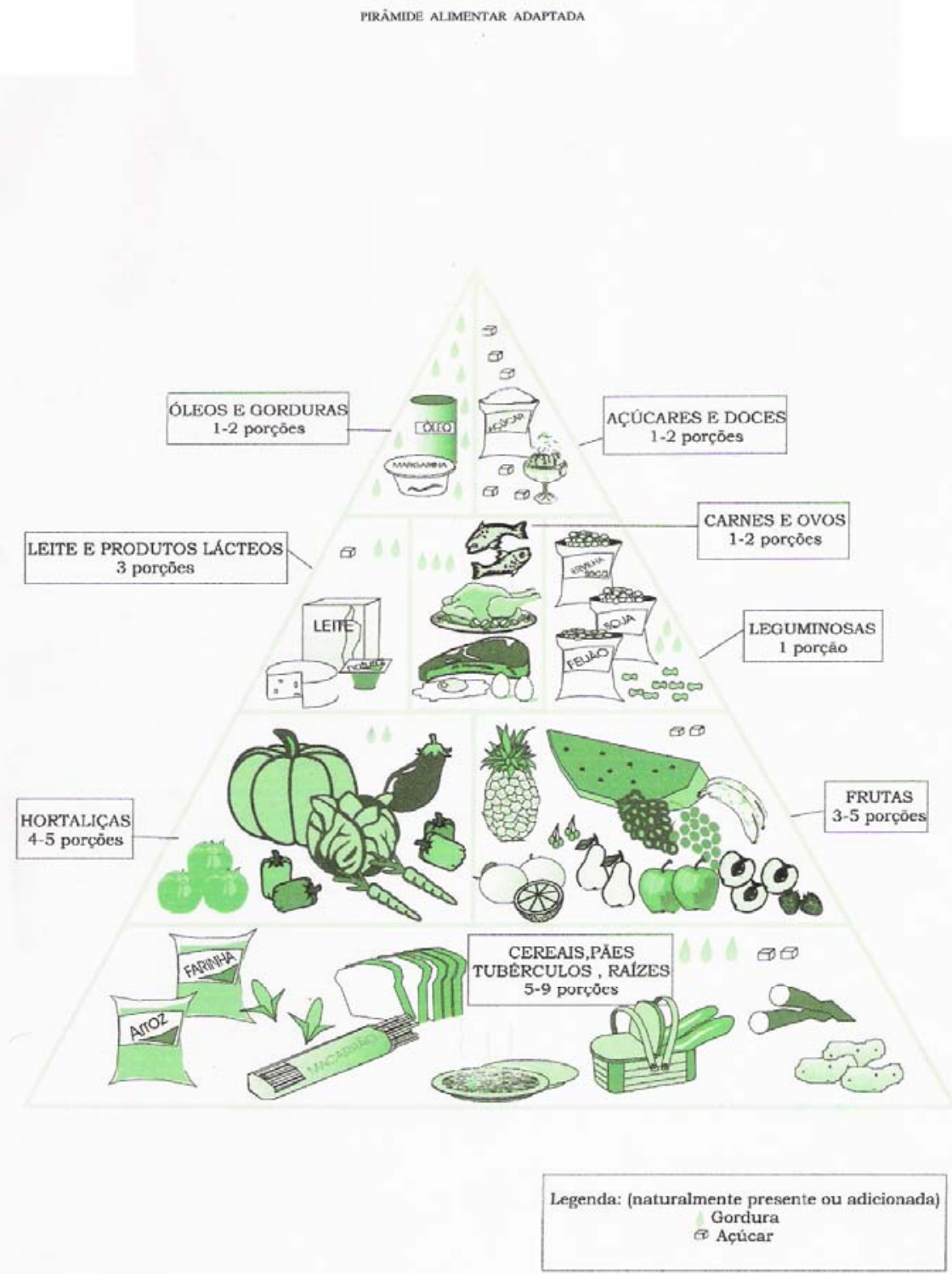

Figura 1. Pirâmide alimentar adaptada

Fonte: PHILIPPI,S.T. et al,1996

Ilustração: Graziela Mantoanelli

Dados de porçōes: software "Virtual Nutri"

Estudos como os de Philippi (1999) e Sávio (2006) mostram bem as dificuldades enfrentadas pelos profissionais para ajustarem as prescrições nutricionais às demandas das pessoas quer seja em nível individual quanto em coletivo. Este fato é reforçado, como visto no capítulo anterior, pela variedade de povos que influenciaram e confirmaram a cultura alimentar brasileira. A especificidade tanto de uma matéria-prima quanto de seu produto final reflete nos estudos que devem ser realizados nos pratos típicos brasileiros. O que nos remete a alimentos vastamente aceitos por populações como o milho e conseqüentemente - a 
pamonha. Produto este que, embora seja típico brasileiro, não é encontrado nem na Pirâmide alimentar e nem na maioria das tabelas de composição nutricional.

Outro ponto necessário de atenção, quando se fala em alimentação saudável, segundo Botelho (2006), é o aumento crescente do consumo de alimentos em estabelecimentos comerciais (restaurantes). Apesar de tentarem lembrar traços da tradição alimentar de cada região, é notória como perdem espaço e características específicas dos pratos regionais.

Concorda-se com Ginani (2004) em relação à preocupação de alguns países terem seus alimentos típicos sendo substituídos progressivamente pelas facilidades da globalização. Fica a responsabilidade de cada cidadão brasileiro resgatar e divulgar sua culinária típica, valorizando assim uma história construída pelos antepassados.

Como uma maneira de clarear e até facilitar a compreensão quantitativa da alimentação saudável, "foram estabelecidos três dietas-padrão: de 1600 kcal, 2200 kcal e 2800 kcal, com distribuição dos macronutrientes: carboidratos (50-60\%), proteínas (10-15\%), lipídios (20-30\%)" (PHILIPPI et al., 1999, p. 65). É importante destacar que, para analisar uma preparação, é necessário, a priori, realizar a Ficha Técnica de Preparação - FTP (AKUTSU et al., 2005). A FTP é instrumento essencial na atenção dietética e o fulcro da alimentação saudável.

Nesse sentido, quando se comprara os resultados obtidos pela análise de composição química (Anexo 6) com as propostas de dietas padrão apresentadas por Philippi (1999), percebe-se que a pamonha é um alimento que pode fornecer entre 15,6\% (para uma dieta de 2800 kcal e com $150 \mathrm{~g}$ do produto da Ficha de Preparação do Anexo A) e 27,2\% (para uma dieta de $1600 \mathrm{kcal}$ e com $150 \mathrm{~g}$ do produto da Ficha de Preparação do Anexo A) dos nutrientes necessários. Portanto, a pamonha é uma preparação com um teor calórico importante podendo, por sua ampla aceitação, ser usado em regiões do Brasil cujas populações requeiram um aporte calórico maior. Mas vale reforçar a necessidade de ajustes em prol da alimentação saudável, uma vez que alimento com muita energia deve ser mais bem trabalhado. 
Assim sendo, os estudos de Ginani (2004), Silva et al. (2003) e Botelho (2006) ficam reforçados na premissa de resgatar pratos tradicionais brasileiros bem como realizar ajustes em termos de receitas sem, no entanto, perder a identidade de cada produto. Desta forma, enfatiza-se a necessidade de trabalhos na Nutrição e na Gastronomia que favoreçam a alimentação saudável.

Foi lançado então o desafio de resgatar a origem da pamonha, uma vez que as referências estudadas citaram o produto em quase todas as regiões: Região Sudeste (em Minas Gerais), Região Norte (no Amazonas), Região Nordeste (nos estados de Pernambuco, Ceará e Piauí), Região Centro-Oeste (no estado de Goiás). E, para tal resgate, pesquisou-se primeiro a história do milho e depois a da pamonha a fim de se ter uma base maior para que seja possível afirmar a origem da pamonha bem como em qual região ela é realmente aceita e tida como prato típico. 


\section{CAPÍTULO 3 - MILHO}

\subsection{HISTÓRIA DO MILHO}

Consumido desde civilizações antigas, como Maias, Astecas e Incas, o milho tem sua origem comprovada por estudos arqueológicos, os quais relatam o México como o berço da produção de milho. E em estudo mais recente Freitas (2001), defende a origem mexicana do milho, utilizando amostras arqueológicas de Januária/ MG. Confirma-se assim o que Cascudo (2004) e Udry et al. (2000) relatam como origem americana do milho (América Central), ilustrado nas amostras de milho utilizadas por Freitas (2001).

\section{Figura 2 - Amostras arqueológicas de milho}

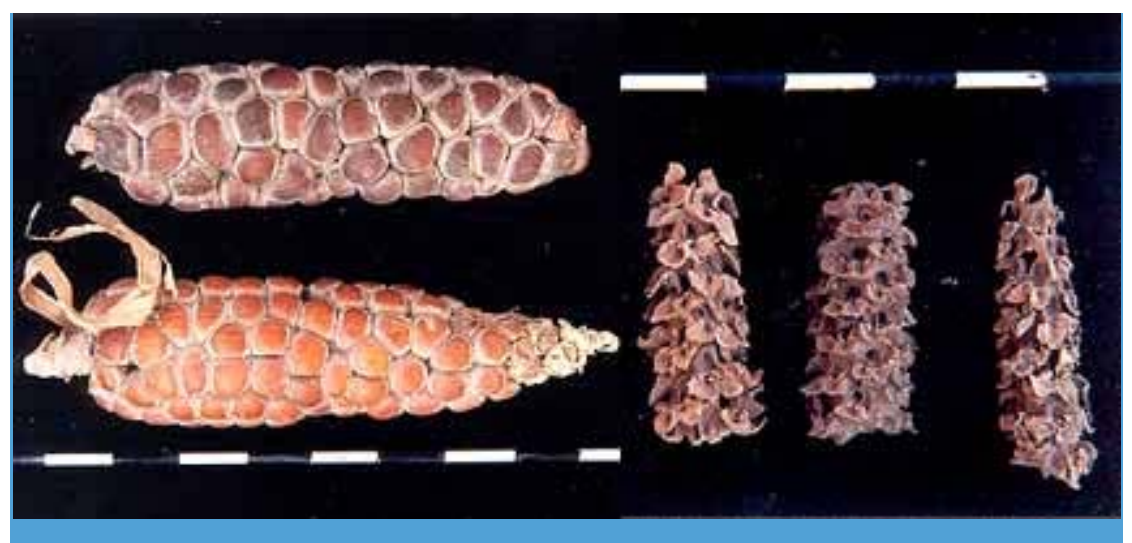

Fonte: Museu de História da Natural da UFMG

Os mesmos autores também relatam o caráter sagrado do milho e de como ele traduzia a relação de sobrevivência homem-milho, uma vez que o milho é uma cultura, e, portanto, não se reproduz; tem que ser plantado, semeado pelas mãos dos homens. Ficou, assim, a cargo dos povos da região da América Central, de 
domesticar o milho e, por seleção, produzir um grande número de espécies. Assim, à medida que os europeus foram chegando às Américas, por volta de 1492, já encontraram vários tipos de milho domesticados e cultivados pelos nativos.

No decorrer de cada interação de povos por meio das colonizações, foi havendo acréscimos nas variedades de milho, o que permitiu melhorias no seu desenvolvimento. Com isso, pôde-se melhorar o milho indígena, que era mais mole, que se prestava mais à moagem e produção de farinhas até chegar nos milhos que tiveram importância no melhoramento genético atual, principalmente o milho Cateto, que tem grãos duros de cor laranja, e o cristal, duro de cor branca (UDRY et al., 2000).

Para Câmara Cascudo (2004), o milho e suas preparações são a síntese, no Brasil, das culinárias do índio, português e africano, atualmente incorporada à indústria do milho.

Para o índio brasileiro, o milho não teve grande importância como a mandioca, mas tinha seu caráter sagrado como relatado na lenda do milho por Fernandes (2004, p. 36):

\begin{abstract}
"Segundo uma lenda guarani, dois guerreiros, depois de terem procurado em vão caça, pesca, ou qualquer alimento para a família, foram avisados pelo grande espírito Nhandeiara que só uma luta mortal entre os dois traria a solução. O vencedor seria enterrado ali mesmo e da sua sepultura nasceria uma planta que alimentaria toda a tribo. Os dois lutaram e Avati foi derrotado e morto. Da sua cova nasceu o milho, avati no idioma tupi." (FRNANDES, 2004, P.36).
\end{abstract}

O milho é uma gramínea pertencente à família Poacese e à espécie Zea mays $L$., sendo que todos os milhos existentes pertencem a essa única espécie. É uma das plantas com maior variabilidade genética, o que permitiu vários trabalhos de sucesso no melhoramento genético, com início por volta de 1930, resultando no que hoje é conhecido como milho híbrido. Essa espécie é obtida de linhagens mais promissoras para capacidade de combinação e o cruzamento entre elas (UDRY et al., 2000). 
Consumido em larga escala, tanto na forma de grãos secos como verdes, o milho utilizado no Brasil, antes da era do híbrido, era o milho cateto e os provenientes do seu cruzamento com milhos americanos dentados. Como grãos verdes para consumo in natura, o milho é conhecido popularmente como milhoverde, e, como tal, pode ser consumido cozido ou assado, processado pra fazer curau, pamonha e suco e, ainda, como ingrediente para a fabricação de bolos, biscoitos, sorvetes, entre outros (UDRY et al., 2000).

No livro "O Cultivo do Milho Verde" (EMBRAPA, 2003), é esclarecido que a designação "milho verde" inclui o milho-doce, mas este não é indicado para alguns processamentos, como na produção de pamonhas, por ter um alto conteúdo de açúcar. O milho comum tem cerca de 3\% de açúcar e entre 60\% e 70\% de amido enquanto o milho-doce tem de 9\% a 14\% de açúcar (SILVA, 1994).

Tradicional no Brasil por seu consumo, o milho-verde teve que ser melhorado, uma vez que a própria variedade do milho inclui variações de adaptações desde a região a ser produzido até a qualidade final que o mercado exige. A demanda crescente por milho verde obrigou as empresas produtoras de sementes a desenvolver cultivares que atendam às exigências do mercado consumidor. Atualmente, entre as centenas de cultivares de milho existentes no mercado brasileiro, apenas 15 são recomendados pelas firmas produtoras de semente como apropriados para milho-verde (EMBRAPA, 2003).

Em termos de produção mundial (PONCIANO et al., 2003), o Brasil ocupa o terceiro lugar (6\%) na produção de milho atrás somente dos Estados Unidos (40\%) e China (20\%). No Brasil, a produção concentra-se nos estados de Minas Gerais $(21,1 \%)$, São Paulo $(20,1 \%)$ e Goiás $(18,69 \%)$ (EMBRAPA, 2003).

Os destinos de produção do milho (Tabela 1) concentram-se na produção para uso animal. No Brasil, a produção de milho, segundo Embrapa (2006), pode ter o destino no próprio estabelecimento rural ou para o mercado consumidor, e é direcionado para fábricas de rações, indústrias químicas, mercado de consumo in natura e exportações. Fica então o esforço de explorar mais o potencial do milho voltado para a alimentação humana, uma vez que, mesmo concentrado naprodução 
animal, a cadeia produtiva que vai da semente ao fubá de milho movimenta em torno de US\$ 10 bilhões.

Tabela 1. Destino da Produção de Milho em Grãos de acordo com o Censo Agropecuário do IBGE de 1996

\begin{tabular}{l|ccc}
\hline \hline \multirow{2}{*}{ Destino da Produção } & Produção & Número de Estabelecimentos & Produtividade \\
\cline { 2 - 4 } & $\%$ & $\%$ & $\mathrm{Kg} / \mathrm{ha}$ \\
\hline Consumo no Estabelecimento & 24,9 & 60,5 & 1,7 \\
Estocada no Estabelecimento & 6,3 & 6,6 & 2,2 \\
Comercializada & 68,7 & 32,1 & 2,9 \\
. Cooperativa & 20,0 & 3,4 & 3,5 \\
· Indústria & 13,4 & 0,7 & 3,8 \\
· Intermediário & 31,5 & 24,8 & 2,5 \\
· Direto ao Consumidor & 3,8 & 3,7 & 2,4 \\
\hline Fonte: IBGE 1996 & & &
\end{tabular}

Em países como o México o milho é a base da alimentação da população, chegando a um consumo per capita anual de 63 quilos enquanto no Brasil não chega aos 19 quilos (EMBRAPA, 2006).

Mesmo não sendo a base da alimentação brasileira, compartilha-se da afirmação de Júnior et al. (2006), que diz que o milho representa uma das culturas mais importantes devido a sua produtividade, composição química e valor nutritivo. E, mesmo não tendo conhecimento em termos técnicos de composição, os brasileiros nativos, por volta do século XVIII, começaram a colocar o milho em lugar decisivo na alimentação nacional. A farinha de milho, no período conhecido como Ciclo do Ouro nas Minas Gerais, passou a substituir a farinha de mandioca. Ainda, era ingrediente de uma bebida energética denominada jacuba (farinha de milho misturada à água fervida com rapadura). Eram esses alimentos que davam energia aos viajantes e tropeiros (FERNANDES, 2004). 
Assim, em termos nutricionais, a própria história do milho permitiu que o mesmo fosse melhorado, chegando atualmente a um cereal com alto teor de energia além de apresentar vitaminas (A e complexo B) e sais minerais (ferro, fósforo, potássio, cálcio, etc.) em sua composição.

A quantidade de nutrientes dos cereais é alterada em função da variedade do grão, condições climáticas e geográficas, tipo de cereal, grau de beneficiamento, entre outros. Os grãos de cereais apresentam estruturação característica e diferenciada. Seus envoltórios e o amido caracterizam seu comportamento não só ao calor, mas também sob ação de outros agentes.

A Tabela 2 apresenta a composição química dos principais grãos e cereais. O que pode ser destacado é que, em termos de nutrientes, o milho está em posição mediana quando comparado aos demais grãos e cereais. Além disso, há uma variação em termos de composição de macronutrientes de uma variedade de milho para outra, o que pode ser conferido na Tabela 3.

Tabela 2 - Composição nutricional de grãos e cereais

\begin{tabular}{l|llllll}
\hline Componente & Arroz & Milho & Trigo & Aveia & Centeio & Cevada \\
\hline Carboidrato g/100g & 81,3 & 69,6 & 70,7 & 62,6 & 68,9 & 73,8 \\
Proteína g/100g & 7,7 & 10,7 & 11,7 & 8,2 & 10,4 & 9,5 \\
Gordura g/100g & 2,2 & 4,3 & 2,1 & 5,6 & 1,2 & 1,6 \\
Fibra g/100g & 0,05 & 1,7 & 2,6 & 8,7 & 3,4 & 1,7 \\
Umidade & 10,2 & 12,3 & 11,3 & 12,3 & 12,7 & 12,6 \\
Cinza g/100g & 0,6 & 1,5 & 1,5 & 2,6 & 2,4 & 1,2 \\
Cálcio mg/g & 23,0 & 150,0 & 43,7 & 88,0 & 54,0 & 38,0 \\
Ferro mg/g & 2,6 & 0,0 & 3,3 & 5,3 & 5,8 & 3,7 \\
Zinco mg/g & 0,0 & 2,5 & 4,1 & 0,0 & 0,0 & 0,0 \\
Tiamina mg/g & 0,0 & 0,0 & 0,0 & 0,0 & 0,0 & 0,0 \\
Riboflavina & 0,0 & 0,0 & 0,0 & 0,0 & 0,0 & 0,0 \\
\hline Niacina & 0,0 & 0,0 & 0,0 & 0,0 & 0,0 & 0,0 \\
\hline
\end{tabular}


Tabela 3- Resultado de Análises Laboratoriais pela UnB - Amostras de Milho

\begin{tabular}{|l|l|l|l|l|}
\hline Tipo de Milho & Proteína & Umidade & Cinzas & Gordura \\
\hline Milho 1051 - amostra 7 & 3,1 & 65,9 & 0,6 & 0,2 \\
\hline Milho 1051 - amostra 8 & 3,3 & 71,1 & 0,6 & 0,3 \\
\hline Milho 1051 - amostra 9 & 3,1 & 69,2 & 0,6 & 0,6 \\
\hline MÉDIA & 3,2 & 68,7 & 0,6 & 0,4 \\
\hline & & & & \\
\hline Milho 3061 - amostra 10 & 2,9 & 76,6 & 0,6 & 0,6 \\
\hline Milho 3061 - amostra 11 & 2,8 & 78,2 & 0,7 & 1,0 \\
\hline Milho 3061 - amostra 12 & 2,8 & 78,2 & 0,7 & 0,7 \\
\hline MÉDIA & 2,8 & 77,7 & 0,6 & 0,8 \\
\hline
\end{tabular}

Confirma-se pelas tabelas os achados de Filho (2003) para o potencial de variedades que o milho oferece. Fato este que se reflete em qualquer preparação feita com o milho.

Torna-se então necessário entender melhor o uso do milho na culinária, uma vez que o mesmo tem um potencial grande de produção que poderá ser utilizado em prol da alimentação humana, preocupação esta compartilhada pelo Ministério da Saúde (BRASIL, 2002).

\subsection{USO DO MILHO NA GASTRONOMIA}

Na conceituação de Ornellas (2001), o milho é exemplo de hortaliças, que são muito importantes por fornecer vitaminas, minerais e aumentarem o resíduo alimentar no trato digestivo. Assim, resgatar o produto pamonha é resgatar uma matéria-prima, que, sendo trabalhada pela gastronomia, poderá garantir uma alimentação apetitosa e nutritiva, que é o objetivo da arte culinária e faz parte da atenção dietética. 
Quando se fala de milho para consumo, pode ser tanto para consumo humano quanto animal. É considerado um dos cereais de maior relevância e que pode fornecer mais de 500 derivados, conforme listados por Ponciano et al. (2003): variedades de milho podem ser usadas em muitas indústrias alimentícias e outras indústrias, como a química (amido, dextrina, glicose, óleo, margarina, fermento, etc.); de bebidas (licores, refrigerantes, vinhos, etc.); de fermentação (enzimas, acetonas, etc.); química e mecânica (fundição de metais, plásticos, etc.); e de rações (grão moído, farelo, germe, etc.). Para fins de ilustração, a Tabela 4 mostra a utilização do milho em diferentes segmentos no Brasil.

Tabela 4 - Exemplos da utilização de milho em diferentes segmentos no Brasil

\begin{tabular}{|c|c|}
\hline SEGMENTO & UTILIZAÇÃO \\
\hline Uso animal direto & Silagem, grãos (inteiros e desintegrados) para aves \\
\hline Indústria de rações & Aves (corte ou postura), suínos, bovinos (corte e leite) \\
\hline Xarope de glicose & $\begin{array}{l}\text { Balas, salsichas, mortadelas, hambúrgueres, frutas } \\
\text { cristalizadas, compotas, biscoitos, xaropes, sorvetes, } \\
\text { polimento de arroz }\end{array}$ \\
\hline $\begin{array}{l}\text { Uso humano direto de preparo } \\
\text { caseiro }\end{array}$ & $\begin{array}{l}\text { Pamonha, espiga, pipoca, pães, bolos, broas, cuscuz, } \\
\text { polenta, angus, sopas, farofa }\end{array}$ \\
\hline $\begin{array}{l}\text { Indústria de alimentos - produtos } \\
\text { finais }\end{array}$ & $\begin{array}{l}\text { Amidos, fubás, farinhas comuns, canjica, óleo, creme, } \\
\text { glicose, dextrose }\end{array}$ \\
\hline $\begin{array}{l}\text { Xarope de glicose com alto teor } \\
\text { de maltose }\end{array}$ & Cerveja \\
\hline Maltodextrina & $\begin{array}{l}\text { Aromas e essências, sopas desidratadas, pó para } \\
\text { sorvetes, } \quad \text { complexos vitamínicos, }\end{array}$ \\
\hline Intermediários & Sêmola, semolina, moído, granulado, farelo de germe \\
\hline Corante caramelo & Refrigerantes, cervejas, bebidas alcoólicas, molhos \\
\hline Dextrina & $\begin{array}{l}\text { Adesivos, tubos e tubetes, barricas de fibra, lixas, sacos } \\
\text { de papel, multifoliados, abrasivos, estampagem de } \\
\text { tecidos, cartonagem, beneficiamento de minérios }\end{array}$ \\
\hline Amido alimentício & $\begin{array}{l}\text { Biscoitos, pó para pudins, fermento em pó, macarrão, } \\
\text { produtos farmacêuticos, balas de goma }\end{array}$ \\
\hline Amido industrial & Papel, papelão ondulado, adesivos, fitas gomadas, \\
\hline
\end{tabular}




\begin{tabular}{|l|l|}
\hline & $\begin{array}{l}\text { briquetes de carvão, engomagem de tecidos, } \\
\text { beneficiamento de minérios }\end{array}$ \\
\hline Ingrediente protéico & Rações para bovinos, suínos, aves e cães \\
\hline Pré-gelatinização & Fundição de peças de metanol \\
\hline Pré-gelatinização & $\begin{array}{l}\text { Rotulagem de garrafas, rotulagem de latas, sacos, tubos } \\
\text { e tubetes, fechamento de caixas de papelão, colagem de } \\
\text { papel, madeira e tecidos }\end{array}$ \\
\hline
\end{tabular}

Fonte: Refinações de Milho do Brasil Ltda.

Embora tenha uma grande versatilidade em termos de uso, o consumo humano direto de milho corresponde a cerca de $5 \%$ da produtividade brasileira (EMBRAPA, 2006), o que desafia o poder público (SAÚDE, 2006), uma vez que mesmo sendo um cereal de alto poder energético, o milho é pouco consumido, mesmo pelas comunidades mais desnutridas. Fica como tentativa governamental enriquecer as farinhas de milho com ácido fólico a fim de permitir um aporte calórico e de minerais.

Em virtude dos altos índices de anemia e de doenças causadas pela deficiência de ácido fólico na população brasileira, o Ministério da Saúde e a ANVISA tornaram obrigatória no ano de 2002 a fortificação das farinhas de trigo e milho (Brasil, 2002). Assim, tornou-se obrigatório o enriquecimento das farinhas de trigo e de milho vendidas diretamente ao consumidor e as utilizadas como matériaprima pelas indústrias com ferro e ácido fólico desde junho de 2004.

Cada $100 \mathrm{~g}$ de farinha de trigo e de milho deverá conter 4,2mg de ferro e 150mcg de ácido fólico. Assim, as farinhas e produtos, como pães, macarrão, biscoitos, misturas para bolos e salgadinhos, deverão apresentar maior quantidade de ferro e ácido fólico em sua formulação final.

Pela Tabela 5, pode-se confirmar o baixo percentual de milho destinado para o consumo humano, deixando claro a necessidade que o País tem de explorar o potencial do milho. 
Tabela 5. Estimativa de Consumo de Milho (mil toneladas) por Setor no Brasil, 1996 e 2000- 2002.

\begin{tabular}{l|cccc}
\hline Segmento & \multicolumn{4}{|c}{ Consumo } \\
\hline \multirow{2}{*}{ Avicultura } & $\mathbf{1 9 9 6 *}$ & $\mathbf{2 0 0 0}$ & $\mathbf{2 0 0 1}$ & $\mathbf{2 0 0 2 * *}$ \\
Suinocultura & 9,8 & 13,0 & 13,5 & 13,9 \\
Pecuária & 7,6 & 8,3 & 8,6 & 8,9 \\
Outros animais & 2,1 & 2,7 & 2,8 & 2,9 \\
Consumo Industrial & - & 1,5 & 1,5 & 1,6 \\
Consumo Humano & 4,1 & 4,0 & 4,2 & 4,2 \\
Perdas/sementes & 1,4 & 1,5 & 1,5 & 1,5 \\
Exportação & 162 & 850 & 263 & 328 \\
Outros & - & - & 5,6 & 1,5 \\
\hline Total & 10,8 & 3,5 & 3,6 & 3,4 \\
\hline Fontes: Abimilho, & $\mathbf{3 6 , 0}$ & $\mathbf{3 5 , 3}$ & $\mathbf{4 1 , 5}$ & $\mathbf{3 8 , 2}$ \\
\hline
\end{tabular}

Fontes: Abimilho, $\left({ }^{*}\right)$ MB Associados, Conab e Safras \& Mercado

Obs: $(* *)$ Estimativa 2002

A comercialização do milho-verde no Brasil acontece de várias formas: desde a venda a granel na própria lavoura até no processo sofisticado de milho cozido a vapor, embalado a vácuo. Normalmente, no processo a granel, o consumidor ou o comerciante adquire o produto na quantidade desejada ou em unidades ou em sacos ou atilho (composto por seis espigas). O milho pode ser vendido com ou sem a palha, lembrando que na compra com a palha deve-se escolher espigas com folhas de cor verde-vivo e cabelo marrom-escuro. Segundo Filho, "espigas de cor amarelada e com casca seca estão fora do padrão comercial" (FILHO, 2003, p. 192).

No Brasil, a Embrapa Milho e Sorgo tem o compromisso de difundir as melhorias obtidas em suas pesquisas e desenvolveu um híbrido de alta qualidade protéica denominado QPM (Quality Protein Maize). A partir de suas pesquisas, a Embrapa Milho e Sorgo publicou o livro "Culinária do Milho e Sorgo" (disponível em http://www.cnpms.embrapa.br/receitas/index.html) com uma coletânea de receitas que buscam soluções para os problemas nutricionais da população brasileira. 
Confirmando as pesquisas da Embrapa, Glória et al. (2004) realizaram um estudo em que foi avaliado biologicamente um suplemento contendo milho QPM e concluíram que este híbrido desenvolvido permitiu adição ao valor nutritivo de produtos utilizando esta variedade, expresso por sua qualidade protéica e com baixa relação custo/benefício.

Para a alimentação humana, o milho se apresenta em diversas formas de grãos secos e verdes. Como grãos verdes, para o consumo in natura, o milho é conhecido popularmente como milho-verde, caracterizado por umidade ao redor de 70 a $80 \%$, podendo ser consumido cozido ou assado, processado para fazer curau, pamonha e suco (FILHO, 2003). Sendo o uso do milho para produção de pamonha também citado por Philippi (2003).

A designação "milho-verde" (normalmente com 3\% de açúcar e 60 a 70\% de amido) inclui o milho-doce, cuja produção é mais voltada para a indústria de conservas, pois seu alto teor de açúcar (cerca de 9 a 14\% de açúcar e 30 a 35\% de amido) torna inviável a produção de alguns pratos como o curau e a pamonha.

Durante o processamento do milho, todas as etapas devem ser muito bem monitoradas (FILHO, 2003) com a finalidade de garantir que a qualidade da matériaprima fique o mais próximo do original, pois o metabolismo da espiga continua ativo mesmo depois da colheita. Assim, como ainda é feita colheita manual para o milhoverde, o ideal é que ela seja iniciada de madrugada quando as palhas estão bem frescas e a temperatura é amena. E o mesmo princípio deve acontecer para o transporte para evitar as horas mais quentes do dia, podendo provocar perda significativa de água em virtude da alta taxa de respiração. Os quais cuidados permitem um maior aproveitamento em termos de nutrientes, permitindo assim, após entender resumidamente a bioquímica do milho, a confecção de produtos mais saudáveis.

A maior parte da composição do milho é de carboidrato e, portanto, é necessário destacar as principais características dessa classe para clarear o comportamento do milho no processamento. Segundo Bobbio (1992) e Barham 
(2002), carboidratos são hidratos de carbono, sendo que o que compõe o milho é o amido, formado por duas frações: amilose e amilopectina.

As moléculas de amilose e amilopectina estão agrupadas e formam grânulos, que são praticamente insolúveis em água fria e podem absorver até $30 \%$ do seu peso sem aumentar o volume dos grãos. Quando aquecido, os grãos aumentam muito a quantidade de água absorvida. E, para cada amido, tem-se um intervalo de temperatura de gelificacão característico como mostrado na Tabela 6:

Tabela 6: Percentual de amilose e intervalo de gelificação dos amidos

\begin{tabular}{l|cc}
\hline \multicolumn{1}{c|}{ Amido } & \% Amilose & Intervalo de gelificação ${ }^{\mathbf{C}} \mathbf{C}$ \\
\hline Mandioca & 19 & $51-63$ \\
Milho & 27 & $62-71$ \\
Arroz & 18 & $61-77$ \\
Batata & 22 & $56-62$ \\
\hline Trigo & 24 & $58-64$ \\
\hline
\end{tabular}

Fonte: Bobbio, 1992.

Outro ponto importante na parte químico do milho é a diferença de solubilidade das moléculas que o compõe, conforme ilustrado na Tabela 7 (BOBBIO, 1992).

Tabela 7 - Solubilidade da Amilose e Amilopectina em Àgua

\begin{tabular}{l|l}
\hline \multicolumn{1}{c|}{ Amilose } & \multicolumn{1}{c}{ Amilopectina } \\
Solúvel em água & $\begin{array}{l}\text { Pouco solúvel ou insolúvel } \\
\text { Menos viscosa }\end{array}$ \\
Cadeias retas e lineares & Cadeias ramificadas \\
Forma helicoidal & Não helicoidal \\
\hline Facilita formação de géis & Não forma géis, exceto em concentrações acima de $30 \%$ \\
\hline
\end{tabular}

Fonte: Bobbio, 1992. 
As proporções de amilose e amilopectina variam entre os amidos de diferentes espécies vegetais, e mesmo entre amidos da mesma espécie, cuja variação deve-se ao grau de maturação das plantas. Amidos do milho contêm relativamente grandes quantidades de amilose (26 a 30\%). Por sua vez, tubérculos, como batata e mandioca, contêm pequenas quantidades de amilose (17 a 23\%) e grandes quantidades de amilopectina (BARHAM, 2002).

O grânulo de amido tem capacidade limitada de absorver água fria (30\% do seu peso em água). No entanto, nos processos de cocção, à proporção que os grãos de amido são suspensos em água e a temperatura é aumentada gradualmente, ocorre o rompimento das ligações de hidrogênio, mais fracas, entre as cadeias de amilose e de amilopectina e os grânulos começam a se intumescer e formar soluções viscosas (BOBBIO, 1992).

A solução se torna esbranquiçada, mais viscosa e forma gel, rapidamente, quando resfriada. A este fenômeno dá-se o nome de gelatinização. Esta é uma das propriedades funcionais mais importantes na preparação de alimentos/refeições e resulta principalmente de interações químicas entre moléculas de água e de amido. $\mathrm{Na}$ indústria alimentícia, o aumento da solubilidade com a gelatinização é a base para a confecção de alimentos pré-preparados, como pudins, purê de batata, polenta, dentre outros (PHILIPPI, 2003).

Quando verde, o milho deve ser cozido para ser utilizado, na forma inteira ou em grãos. Quando maduro, adquire coloração amarela, perde parte de sua umidade, e assim pode ser estocado por mais tempo. É utilizado como matéria-prima para fabricação do fubá, de onde se preparam o cuscuz, a polenta, pães, bolos. É também matéria-prima para obtenção de óleo, farinha, xarope de milho, bebidas destiladas (FILHO,2003).

As variedades de milho se diferenciam pela composição do endosperma. $O$ milho para pipoca se caracteriza por possuir grãos pequenos e duros que têm a capacidade de estourar quando aquecidos em temperatura próxima a $180^{\circ} \mathrm{C}$, se 
diferenciando, deste modo, do milho comum. Apresenta camada protéica que envolve grânulos de amido ricos em amilose (FILHO,2003).

O milho amarelado é utilizado tanto para alimentação animal como para a fabricação industrial de salgados chips, tortilas e tacos. Apresenta baixa concentração de amilose. A concentração de amilopectina na extremidade do grão produz uma depressão ou um dente quando este é desidratado (EVANGELISTA, 1998).

Um outro tipo de milho é utilizado para a fabricação de farinhas por apresentar baixa concentração protéica e maiores concentrações de amido, enquanto outra variedade é o milho doce que armazena mais açúcares que amido e apresenta grãos translúcidos e pele menos resistente (FILHO, 2003).

O milho pode apresentar grãos de diversos tamanhos, amarelos ou brancos. O milho para canjica, branco e sem gérmen, é base para uma espécie de sopa doce, também chamada de mungunzá. É obtido por um processo em que o milho é colocado em uma solução fraca de barrela $^{1}$, que faz com que a casca e o gérmen sejam separados do endosperma. Após a obtenção do endosperma, ele é lavado e secado para obtenção do milho para canjica. Ressalta-se que o milho utilizado para o preparo de tortillas passa pelo mesmo processo (PHILIPPI, 2003).

Vários produtos farináceos podem ser obtidos a partir do milho; as variações se dão ou pela granulação ou pela presença de outras substâncias não amiláceas. Xerém - milho pilado grosso, utilizado como comida para animais ou para o preparo de papa, farinha de milho amarela e branca, flocos de milho crus e pré-cozidos, fubá, fubá de canjica, sêmola de milho e amido de milho (BARHAM, 2002).

\footnotetext{
${ }^{1}$ Barrela - Relacionada à palavra latina que significa lavar. Originalmente, referia-se a soluções muito alcalinas obtida por meio da adição de cinzas de madeira em água, que formavam o carbonato de potássio. Atualmente, se refere ao hidróxido de sódio (soda cáustica).
} 
Nas farinhas de milho, a principal proteína encontrada é a zeína que apresenta baixa capacidade para reter gases, no entanto, forma uma massa elástica. É processada a partir do milho seco e apresenta de 7 a 8\% de proteína. Na América do Sul, é obtida a partir do grão inteiro e apresenta menor tempo de vida útil por conter o gérmen. É utilizada em produtos de panificação como pães, bolos e broas e, no preparo de farofas (PHILIPPI, 2003).

A pamonha também pode ser produzida com flocos de milho, mas no Brasil é comum prepará-la com o milho verde, retirado da espiga e ralado em ralo grosso, sem peneirar. A preparação pode ser doce ou salgada em função dos ingredientes acrescidos.

O amido de milho é uma farinha extraída do endosperma do milho. Utilizado como agente espessante em pudins, molhos, sopas, mingaus e na fabricação de produtos assados leves como cookies e muffins, por conferir textura mais fina e compacta. Normalmente é acrescida ao final do processo na fabricação de geléias, compotas e pudins, pois o calor e a presença de ácidos favorecem a hidrólise da molécula e assim enfraquece seu poder espessante (ORNELLAS, 2001).

Entre as bebidas destiladas originadas do milho, destaca-se o Bourbon. Esta bebida tem sabor e teor alcoólico forte é proveniente do condado de mesmo nome na França e que possui percentual de 5 a $51 \%$ de milho destilado em sua composição. O xarope de milho é obtido a partir da quebra de moléculas de amido, por ação enzimática, até se obter um xarope composto por uma mistura de açúcares. A mistura final, xaroposa, recebe o nome de xarope de milho e é utilizada como adoçante, em bebidas não alcoólicas e em manteiga de amendoim. É utilizado no preparo de caldas açucaradas para produtos em que não se deseja cristalização como pé-de-moleque, pirulito e marshmellow (UDRY, 2000). 
Como relatado, o milho tem uma enorme utilização tanto na forma in natura como modificado. Entre as inúmeras possibilidades, será destacado no próximo capítulo, os aspectos históricos e origem da pamonha. 


\title{
7. CAPÍTULO 4 - PAMONHA
}

\subsection{HISTÓRIA DA PAMONHA}

Segundo Cascudo (2004), o povo brasileiro herdou do indígena o mingau, o pirão, a paçoca, a pamonha, a canjica, a pipoca. As culinárias originais foram lapidadas pelo tempo, por mãos africanas e portuguesas para se chegar aos dias de hoje. Mas em termos históricos não há consenso em qual estado brasileiro a pamonha é tida como prato típico.

Vale referenciar as seguintes palavras de Freitas (2001, p. 3-4):

\begin{abstract}
"Questões como quais populações humanas que foram as responsáveis pela domesticação das plantas cultivadas que os índios já possuíam quando da época do contato com os europeus; aonde estas foram domesticadas; quando; como foi a difusão destas plantas pelas diversas regiões das Américas; quem as difundiu; como eram as primeiras raças domesticadas e quais surgiram depois, aonde e quando; por onde as populações humanas migraram; o que levavam nestas andanças (plantas, animais, ferramentas,...); quais eram as culturas que mantinham contato entre si e o que trocavam, apenas citando alguns questionamentos entre tantos outros que podemos formular, possuem dificuldade de serem respondidas, sendo que algumas talvez fiquem para sempre sem resposta." (FREITAS, 2001, p. 3-4).
\end{abstract}

Apesar dos vários questionamentos, compartilhou-se da preocupação do Ministério da Saúde (Brasil, 2002) ao elaborar um guia que trata dos Alimentos Regionais Brasileiros. Com isso, certifica-se que a valorização dos alimentos regionais encoraja o orgulho e a auto-suficiência de uma comunidade. 
Em verdade é tarefa difícil determinar a origem e a tipicidade de uma única localidade para um alimento que foi tão fortemente incorporado e re-elaborado por um povo, cuja característica principal é a miscigenação de raças e costumes.

Quando se fala em pamonha, depara-se com especificidades de receitas de acordo com cada região brasileira. Foi adotada então a especificação de produção do Centro-Oeste, mais precisamente de Goiás, onde o produto pamonha pode ser encontrado em pamonharias das cidades, mercados e até em rodovias (ARAÚJO et al., 2005). Nesses locais, está à disposição o produto já cozido, pronto para o consumo ou em raras exceções, congelado cru, o que proporciona, quando cozido para consumir, um sabor próximo ao do produto recém-preparado.

Foi relevante pesquisar em dicionários a palavra "milho" para que fosse possível registrar as várias possibilidades de uso do milho na culinária bem como nos deparar com as várias interpretações da origem da pamonha. Para Algranti, "do milho podem ser preparados saladas, suflês, pamonhas, pudins, cremes, curau, croquetes, etc. Pamonha é uma especialidade brasileira que na língua tupi é chamada de Pamunã" (ALGRANTI, 2000, p. 382). Ele ainda afirma que as pamonhas mais famosas são as de Goiás.

Reafirmando o que foi colocado no capítulo anterior e concordando com Algranti (2000), Gonsalves (1992) revela que o milho pode ser usado de várias formas: cozido, refogado, em pratos salgados (polentas, cuscuz) e doces (curau, pamonha, mingaus), como pipoca, etc.

Com o intuito de se confirmar a afirmação de Cascudo (2004) de que a origem da pamonha é indígena e de saber em que região brasileira ela é considerada prato típico, foram consultadas outras fontes. Carvalho (1998) pincela influências indígenas na culinária goiana, com destaque para a pamonha, mas acredita que ela foi herdada de Minas Gerais, e tinha a banha de porco como um de seus ingredientes. Algranti (2000) também compartilha da origem indígena da pamonha, mas não deixa a certeza se é um prato típico de Goiás ou São Paulo. Já Freyre (2000) e Cascudo (2004), afirmam a herança indígena da pamonha. 
Em recente trabalho, em que são avaliados os hábitos alimentares em Goiás, Péclat (2005, p. 215) enfatiza:

\begin{abstract}
"a comida seduz, produz magia, sentimento de prazer [...] Comer certos pratos que carregam a identidade de um povo é também, 'comer' parte de uma memória. Memória esta, que elege ou delega a certos pratos a importância de ser o carro chefe da culinária local, e, portanto, da sua identidade." (PÉCLAT, 2005, p. 215).
\end{abstract}

Embora seja também referenciada como prato típico de São Paulo, Minas Gerais, Nordeste e não tenha sido contemplada como prato típico da Região CentroOeste no estudo de Silva et al. (2003), adotou-se neste trabalho a linha de Péclat (2005) e Carvalho (1998). Esses autores colocam a pamonha como prato típico goiano.

Carvalho (1998) aponta as várias heranças culturais de Goiás, tais como: influência dos índios com o uso quase obrigatório da farinha de mandioca; dos bandeirantes paulistas com o feijão-mulatinho; dos nortistas com os peixes de água doce; dos nordestinos com a carne-de-sol e a carne-seca; e do estado de Minas Gerais com o milho verde, o angu e as pamonhas.

Além disso, foi adotado o estudo arqueológico de Freitas (2001) com amostras de milho de Minas Gerais, que comprovou a origem mexicana do milho. Ginani (2004) referencia que o estado de Goiás tem origem remota (1592) e, assim, herdou de Minas Gerais a pamonha, inicialmente na forma doce, herança dos índios. Coube ao povo goiano incrementar a pamonha e hoje oferecê-la em muitas versões, como salgada, com lingüiça, com pequi, com coco, etc.

Péclat (2005) diferencia comida e alimento de tal maneira que o alimento fica ligado à mera satisfação de corpos biológicos. Já a comida, é como um ritual, carregando em si um ato social. Nesse contexto, a pamonhada em Goiás não é mais um prato, uma iguaria; tornou-se uma reunião social, onde o dia começa com a colheita do milho (FIBERG, 2002). Outro fator agregado pela pamonhada, segundo Péclat (2005), foi a entrada dos homens na cozinha para realizar tarefas como cortar, selecionar e ralar o milho. 
Com o papel de agregar famílias, a pamonhada tem sido esquecida, ficando apenas na lembrança e que alguns estabelecimentos comerciais tentam resgatar. Porém, é possível que quem come uma pamonha consiga resgatar as lembranças "da cozinha da vovó e dos tempos dos quintais" (PÉCLAT, 2005).

Adotando as linhas de pesquisas que colocam a pamonha como um prato típico do estado de Goiás, Fernandes complementa as demais linhas, afirmando que "nossa pamonha é de origem indígena. A palavra vem do tupi, pamunha, e até hoje é um quitute saboreado quase que em todas as regiões brasileiras. Em Goiás a pamonha recebe um verdadeiro culto" (FERNANDES, 2004, p. 148). Para Fisberg (2002), embora a pamonha possa ser originária de Minas Gerais e/ou São Paulo, sua forma de preparo consolidada em Goiás é típica.

\subsection{RECEITAS E PROCESSAMENTO DA PAMONHA}

Quando se fala de milho-verde para a produção de pamonhas, existem poucos trabalhos de estudo nesta área, mas em um trabalho desenvolvido na Universidade Federal de Goiás (UFG) em 2004 intitulado "Avaliação de Cultivares de Milho para o Processamento de Pamonha" foi comprovado o híbrido AG 1051 como o melhor para produção de pamonha. Esse estudo teve que observar a grande variabilidade genética do milho quanto à adaptabilidade em diferentes condições ambientais. Constata-se variabilidade para praticamente todos os caracteres da planta, dos grãos e da espiga, assemelhando-se aos estudos de Cardoso et al. (2004), que enfatizaram a necessidade de mais pesquisas com variedades de híbridos.

Para trabalhar com o produto pamonha na região Centro-Oeste, usou-se como referência o estudo de Alves et al. (2004), que relata que, diante da atual necessidade de um mercado consumidor exigente para uma produção de milho durante o ano todo, teve-se que desenvolver tipos de milhos que atendessem a esse mercado. Mais especificamente para o mercado do milho verde, segundo Oliveira et al. (1987), as características quantitativas são o comprimento de espiga com palha 
quando o milho se destina às feiras livres e quitandas, e o peso de espigas sem palha quando o milho se destina aos supermercados. Já no caso do milho para pamonha, é necessário que ele tenha alta produtividade (peso de espigas com palha e sem palha), alta capacidade de produção de massa e uma baixa produção de quirela.

Nesse estudo, Alves et al. (2004) mediram o peso das espigas com palha no mesmo dia da colheita e o peso das espigas, no mesmo dia, sem palha. Depois, as espigas foram raladas em ralador de aço inoxidável e a massa obtida foi passada em peneira com malha de 3,0 mm. Nesta etapa pesou-se a massa coada e a quirela. Avaliou-se também peso da palha, peso de sabugo, diâmetro da espiga e do sabugo a fim de calcular a profundidade do grão, uma vez que, para a produção de pamonhas, a profundidade dos grãos está associada a uma maior produção de massa. Outros pontos foram analisados neste estudo da UFG, entre eles, a avaliação das espigas com palha armazenadas por sete dias sob temperatura ambiente e sob refrigeração.

Como resultado dos estudos, Alves et al. (2004) concluiu que o híbrido AG 1051 é o mais recomendado para o mercado de pamonharias, pois apresentou características desejáveis, como produtividade (maior peso de espigas com palha e sem palha), alta capacidade de produção de massa e baixa produção de quirela. Sendo que tais atributos são dependentes do ponto de colheita do milho, o qual deve ser, no "ponto de pamonha", com umidade entre 60 e 70\% (FILHO et al., 2000) conforme ilustrado na Figura 3.

Embora sabendo qual o melhor híbrido indicado para a produção de pamonha, o resgate de sua origem pode ajudar a elucidar também a origem da pamonha. Em um estudo genético realizado por Freitas (2001), foi comprovado que amostras de milho encontradas em cavernas do Vale do Peruaçu (Januária/ MG) vieram do México, corroborando a linha seguida por Cascudo (2004) e Udry et al. (2000). Aí vem o questionamento: será então que a pamonha não seria uma comida típica de Minas Gerais? Ou será que ela veio de lá e fixou-se como prato típico de Goiás? 
Figura 3 - Milho no ponto de colheita para pamonha

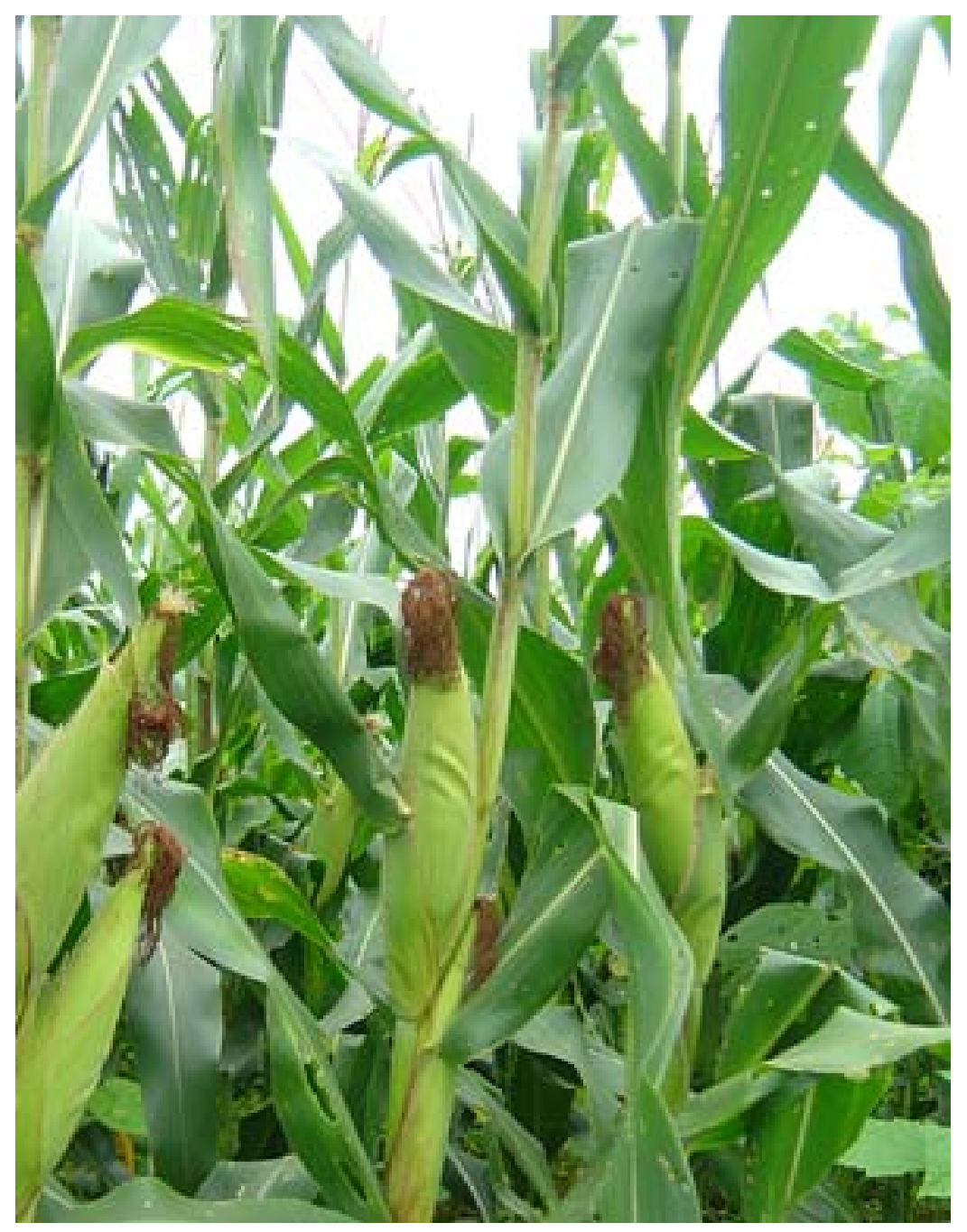

Fonte: Empresa do Centro-oeste produtora de pamonhas

Assim como há variações em termos da regionalidade da pamonha, também há em suas receitas. Entretanto, seu ingrediente básico, o milho ralado, não varia e sua forma mais comum pode ser ilustrada na Figura 4. As variações podem ser em termos de maior ou menor quantidade de açúcar e/ou sal. A questão mais variável é o composto lipídico da pamonha, que pode ser gordura animal (banha de porco, creme de leite, manteiga) ou gordura vegetal (margarina, óleo de soja). Outros ingredientes podem fazer parte da receita, como queijo, lingüiça, pimenta, coco, carne suína, entre outros, reforçando as premissas de Ornellas (2001): a arte culinária modifica alimentos e os torna mais apetitosos e de mais fácil digestão. Ou seja, a técnica de preparo é o que, de fato, torna um produto típico. 
Figura 4 - Pamonha pronta para consumo

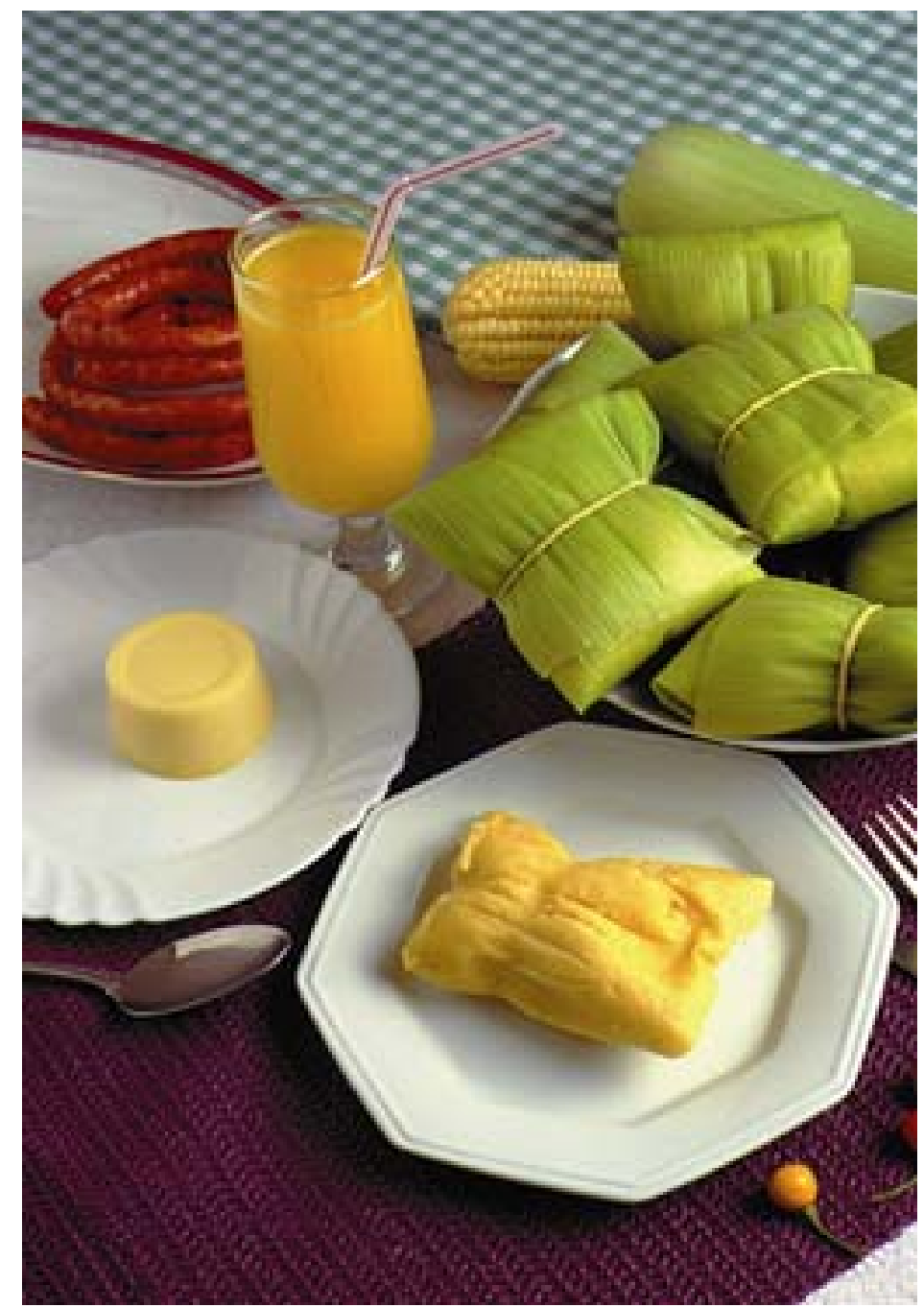

Fonte: Pamonharia do Centro-oeste

Em Goiás, as pamonhas são comercializadas nas feiras, restaurantes e lanchonetes das cidades e das rodovias. Além da pamonha, também é vendida a polpa do milho ralada como uma massa para que as pamonhas possam ser confeccionadas em casa. A pamonha salgada cozida é a preferida diante das outras opções como frita ou assada, podendo ser acompanhada por manteiga e café. E o preparo tradicional da pamonha ocorre em família, na época da safra do milho, sendo denominada esta reunião social como "pamonhada", conforme descrito por Fisberg (2002). 
Viaja-se ao passado sobre o modo como era feita a pamonha, segundo Fisberg (2002, p. 164):

\begin{abstract}
"é como viajar no tempo e relembrar. Ficar um dia inteiro fazendo pamonha e mingau: colhia-se a espiga, retirava-se o 'cabelo', lavava-se a espiga, ralava-se em ralo grosso, passava-se em peneira para fazer a pamonha e coava-se em pano para fazer o mingau. Nesta etapa, a equipe se subdividia em duas: uma para preparar o mingau, que ia ao fogo com leite e açúcar, até engrossar, e a outra para temperar a massa da pamonha: pamonha doce, pamonha salgada, pamonha com queijo, sem queijo, com carne, sem carne, com pimenta etc....Uma vez pronta a massa, enrolava-se na palha do próprio milho.... Alguns preferiam enrolar a pamonha na folha de bananeira. Deixava-se cozinhar, imersa em água, em tacho grande." (FISBERG, 2002, p. 164).
\end{abstract}

Para caracterização da pamonha, adotou-se uma receita básica fornecida por empresa tradicional na produção de pamonhas no estado de Goiás há cerca de 30 anos, atuando no ramo de lanchonete e restaurante, fornecendo a maior parte da matéria-prima por ela processada. Por ser uma empresa de referência para a população goiana, como relatado pela imprensa do SEBRAE (2006), foi adotada sua receita.

A receita básica, a partir da variedade de milho AG 1051, pode ser mais bem visualizada na Ficha Técnica de Preparação - FTP (Anexo 6), que inclui $1 \mathrm{Kg}$ de massa ralada (aproximadamente 10 espigas); açúcar cristal (300g para a versão doce e 1 colher de sopa rasa para a versão salgada); sal (1 colher de café rasa para a versão doce e 1 colher de sopa para a versão salgada); margarina (1 colher de sopa para os dois casos); óleo de soja (150 ml para os dois casos). Como opcionais mais usados, $1 / 2$ colher de chá de fermento em pó, $70 \mathrm{~g}$ de creme de leite e $100 \mathrm{~g}$ de queijo ralado.

Para se preparar, todos os ingredientes são colocados no mesmo recipiente e, em seguida, o óleo quente para escaldar. Pode ser acrescido grão fresco de milho na massa, creme de leite ou queijo ralado (Figura 5). 
Figura 5 - Etapas da produção caseira de pamonha
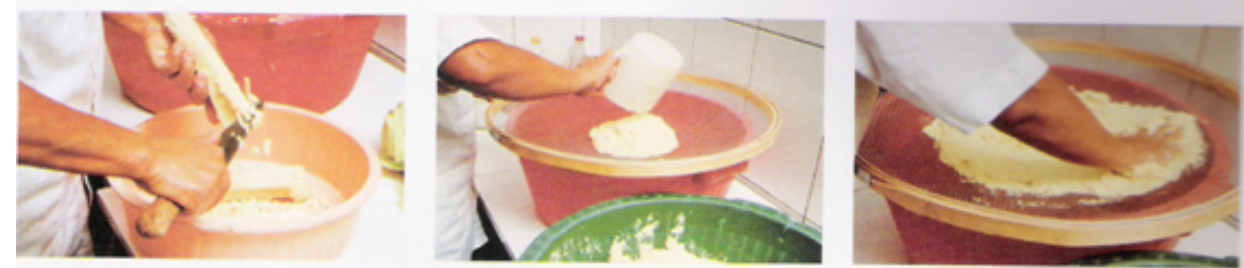

Nes fotus, malioniles ne Pamoekierie da Voud, on Coibinis as odries etagus do trabalkosa e dericaila realicagabo da pamonha. O milko
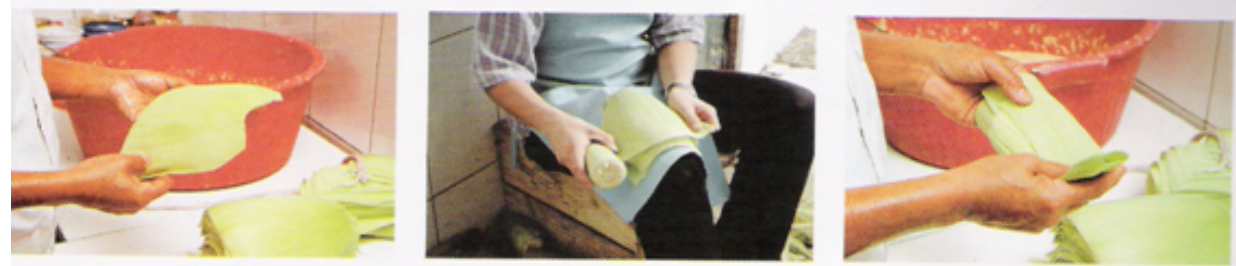
verde é ralado e depois as espigas sdo raspadas à faca para total aproveitamento. A massa é temperada. coada, e depois recheria as palhas de milko
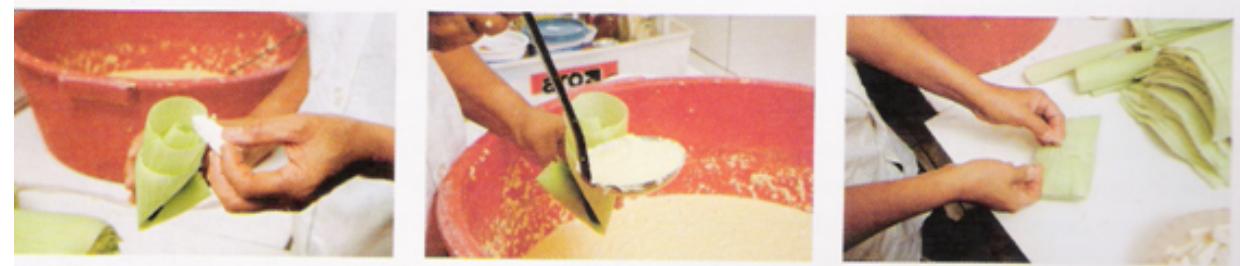
que, logo depois de serem retiradas das espigas, ficam abertas nas coxas para facilitar o sea manuseio

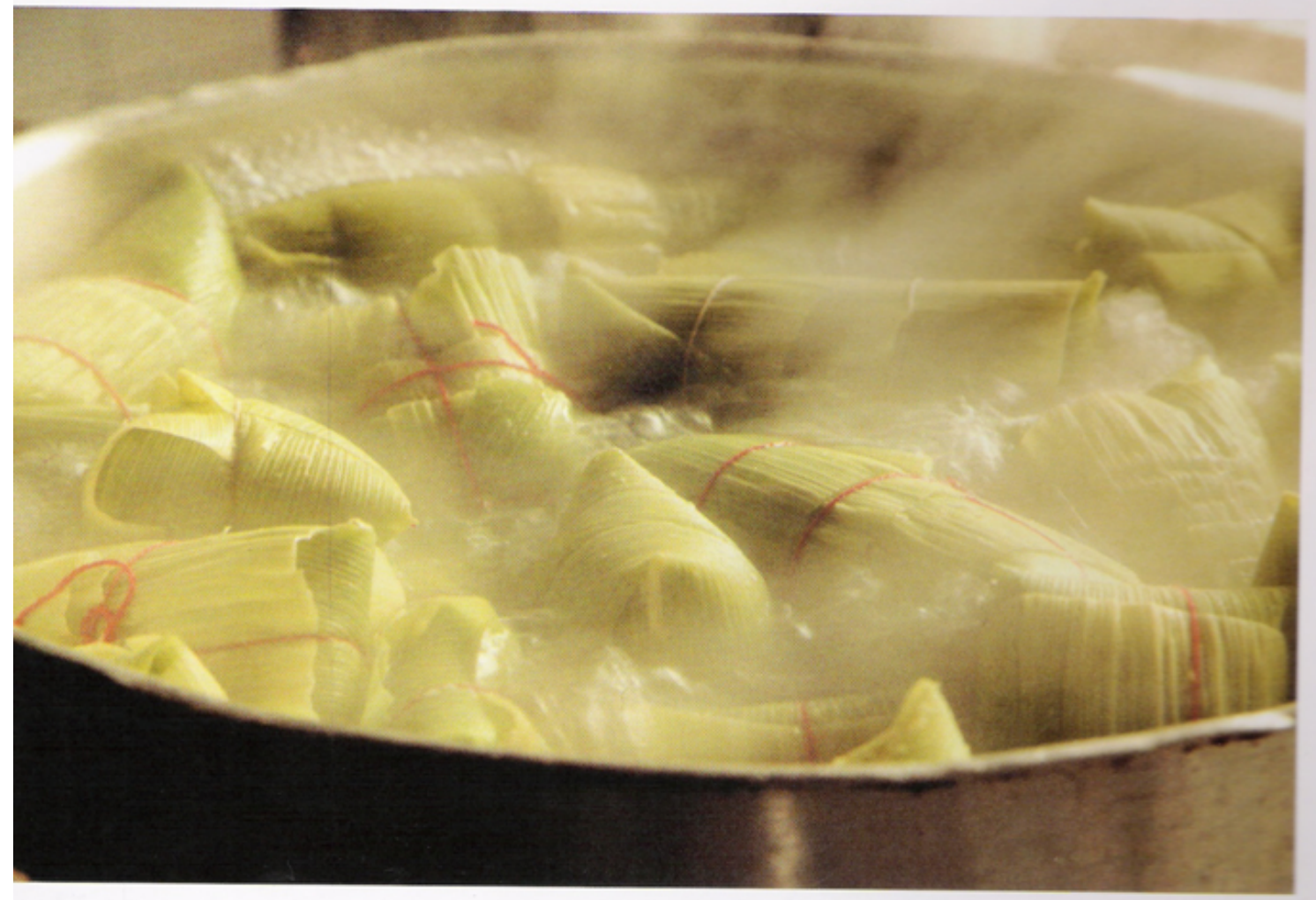

Fonte: Fernandes, 2003 
A embalagem é feita das palhas frescas, de preferência as maiores e macias. Fazem copinhos onde são colocadas a massa e uma fatia de queijo (preferencialmente mussarela). Depois, fecha-se o copinho envolvendo outra palha e finalmente o amarra com linha própria ou elástico (mais usado). No momento da montagem da pamonha, podem ser acrescentados outros ingredientes: coco ralado, lingüiça, pimenta, etc.

Após envase, as pamonhas são colocadas em caldeirões de água fervendo contando de 30 a 35 minutos após nova fervura da água para que as palhas fiquem amareladas, confirmando que a pamonha está cozida. Conforme ilustração a seguir.

Como a grande maioria dos produtos típicos da culinária brasileira, a pamonha ainda é, em sua maioria, produzida de maneira artesanal. Isso reforça a necessidade de ajustes, uma vez que a própria forma de consumo (feita em um dia e armazenada em refrigeração ou caixa térmica para comercialização posterior), segundo Leme (2004), permite alterações microbiológicas e nutricionais.

Seguindo os principais objetivos expostos por Ornellas (2001) para as técnicas dos alimentos na produção/cozinha, que são nutricionais, higiênicos, digestivos, sensoriais e econômicos, compartilhamos os resultados do trabalho de Leme (2004). Neste trabalho, foi analisado o processamento da qualidade do creme de milho verde (pamonha) produzido no município de Piracicaba - SP. E, como resultados, houve uma preocupação quanto aos princípios técnicos de Ornellas (2001) pelo fato de a pamonha ainda ser considerada um produto artesanal. Essa preocupação se deve às questões higiênico-sanitárias e, caso não sejam não respeitadas, podem alterar até mesmo a palatabilidade e a segurança do produto.

Ainda no estudo de Leme (2004), ficou constatado, conforme ilustrado na Tabela 8, que não houve alterações do produto quando armazenado sob refrigeração ou congelamento, sem variações nos quesitos físicos (acidez -pH-, acidez titulável, sólidos solúveis totais - ${ }^{0}$ brix) e físico-químicos (umidade, amido, carboidratos solúveis totais, fibra total -fibra solúvel e fibra insolúvel -, cinzas, lipídios, proteína bruta). 
Tabela 8: Tabela de características físicas e físico-químicas da pamonha durante período de comercialização

\begin{tabular}{l|c|c|c}
\hline & $\begin{array}{c}\text { Início da } \\
\text { comercialização } \\
\text { (Hora inicial) }\end{array}$ & $\begin{array}{c}\text { Final do dia } \\
\text { de comercialização } \\
\text { ( 10h após) }\end{array}$ & $\begin{array}{c}\text { Início do dia seguinte, } \\
\text { depois da refrigeração } \\
\text { ( 24h após) }\end{array}$ \\
\hline Acidez & 7,21 & 6,73 & 6,36 \\
$\mathrm{PH}$ & 0,06 & 0,09 & 0,13 \\
Acidez titulável (NaOH N/100 g & 23,6 & 23,3 & 23,3 \\
amostra) & & & 62,4 \\
\hline Sólidos solúveis totais ( ${ }^{\circ}$ brix) & 63,0 & 63,4 & 12,8 \\
\hline Composição (\%) & 11,8 & 12,8 & 20,4 \\
\hline Umidade & 20,0 & 19,9 & 2,0 \\
\hline Amido & 2,5 & 1,6 & 0,3 \\
\hline Carboidratos solúveis totais & 0,5 & 0,4 & 1,7 \\
\hline Fibra total & 2,0 & 1,2 & 0,3 \\
Fibra solúvel & 0,3 & 0,4 & 0,3 \\
Fibra insolúvel & 0,2 & 0,2 & 1,7 \\
\hline Cinzas & 2,1 & 1,7 & 6,9 \\
\hline Lipídios & 6,3 & 6,6 & \\
\hline Proteína bruta & & & \\
\hline Textura (Ibf/g) & & & \\
\hline Fonte: Leme 2004 & & & \\
\hline
\end{tabular}

Fonte: Leme 2004

A Tabela 9, na qual estão registrados os resultados de análises laboratoriais realizadas pelo laboratório de Agronomia da UnB (Universidade de Brasília) e com amostras fornecidas por empresa produtora de pamonha no Estado de Goiás deixa claro que as variações em termos de composição nutricional, especificamente macronutrientes, depende de muitos fatores como a variedade da matéria-prima utilizada até em que forma o produto final é produzido e comercializado. 
Tabela 9 - Resultado de Análises Laboratoriais pela UnB - Amostras de Pamonhas pasteurizada (crua) congelada

\begin{tabular}{|l|c|c|c|c|}
\hline & Proteína & Umidade & Cinzas & Gordura \\
\hline Pamonha 1051 -amostra 1 & 5,0 & 63,7 & 1,7 & 6,2 \\
\hline Pamonha 1051 -amostra 2 & 3,7 & 59,6 & 1,7 & 8,2 \\
\hline Pamonha 1051 -amostra 3 & 4,6 & 60,5 & 1,7 & 7,5 \\
\hline \multicolumn{7}{|c|}{ MÉDIA simples } & 4,4 & 61,3 & 1,7 & 7,3 \\
\hline Pamonha 3061 -amostra 16 & 2,5 & 66,9 & 1,0 & 9,8 \\
\hline Pamonha 3061 -amostra 17 & 2,6 & 70,5 & 1,0 & 12,4 \\
\hline Pamonha 3061 -amostra 18 & 2,6 & 71,9 & 1,1 & 14,4 \\
\hline MÉDIA simples & 2,6 & 69,8 & 1,0 & 12,2 \\
\hline
\end{tabular}

Diante de estudos relatando a história do milho e posteriormente da pamonha e compartilhando de informações como as de Leme (2004), tem-se reforçado o desafio de resgatar um produto da culinária brasileira, bem como tentar melhorá-lo tanto em termos de sabor quando de hábitos de vida saudável.

Entender e resgatar o caminho histórico de um produto permite exaltar a cultura do povo ao qual ele representa. No entanto, permanece desafiante o ajuste em termos de qualidade nutricional dos produtos típicos para que atuem nas premissas de uma alimentação saudável. 


\section{CONCLUSÃO E DISCUSSÃO}

Fazer um resgate histórico do milho é viajar na construção histórica do Brasil de modo a elucidar e valorizar a riqueza do nosso país. Respeitar e valorizar o regionalismo é questão sine qua non após todos os pontos colocados.

Elucidar, através da revisão bibliográfica do milho e da pamonha, que o milho, matéria-prima principal da pamonha, é originário do México através de amostras arqueológicas da região de Minas Gerais, fez com que a questão da regionalidade da pamonha fosse esclarecida. Assim, pode-se afirmar que a pamonha é originária dos índios e que, embora nascida em Minas Gerais,, foi carregada pela história e fixou-se como comida típica de Goiás.

Diante dos resultados obtidos neste trabalho, fica claro que o desafio é o de resgatar pratos típicos da culinária brasileira, analisá-los de maneira cultural e abordá-los da perspectiva da alimentação saudável buscando sobretudo harmonia entre prazer e saúde.

É importante destacar que a qualidade organoléptica da pamonha, seu maior atributo para a população, é indissociável das qualidades nutricionais, e que o milho é importante não só por seu consumo in natura mas também por seus atributos químicos, importantes para elaboração de produtos alimentícios e não alimentícios.

No decorrer dos estudos, ficou claro que antes de tudo deve ser feito um resgate cultural da pamonha, que abriria as portas para trabalhos futuros, uma vez que, quando detectam-se alterações em um produto, deve-se analisá-lo da perspectiva química, nutricional e cultural, pois as origens de um alimento não é apenas uma questão fisiológica, mas também cultural. 
Concluiu-se este trabalho com mais convicção de que o primeiro passo para tornar a pamonha até mesmo um alimento da lista de bens imateriais do Iphan foi dado. Cabe agora aos novos estudos aceitarem o desafio de analisar quimicamente a pamonha e suas possíveis variações organolépticas. Este segundo passo trará possibilidades tanto para o mercado que trabalho com a venda deste produto bem como poderá enobrecer a cultura goiana. Referenciar a pamonhada e divulgá-la pode ser um impulso no resgate da família, uma vez que, como citado neste trabalho, a pamonha é um ritual que reúne toda a família em prol de um único produto, possibilitando até a atuação de homens, mulheres, idosos e crianças em uma ação gastronômica.

Fazer um resgate cultural da pamonha possibilita a valorização da história de um povo que tem suas origens compartilhadas com tantas culturas, mas que fez da sua culinária a caracterização de cada região do país. Assim, concorda-se com Ginani (2004), quando se busca preservar costumes e hábitos alimentares, está se fortalecendo um dos pilares culturais da identidade cultural de uma sociedade.

Estudar comida, segundo Péclat (2005), deve ser uma ação conjunta multidiciplinar, pois a cultura gastronômica é resultado de toda uma evolução histórica herdada de povos diversos.

Este trabalho enseja que esta seja a primeira etapa na busca do resgate cultural da gastronomia brasileira, uma vez que a partir de um produto específico - a pamonha mais produtos de milho possam ser analisados. Fica então o estimulante desafio de realizar estudos em torno da composição nutricional deste produto bem como de assegurar maneiras de torná-lo com melhores características organolépticas e saudáveis. 


\section{REFERÊNCIAS}

ALGRANTI, M. Pequeno Dicionário da Gula. Rio de Janeiro: Record, 2000.

ALVES, S. M. de F. [et al.]. Avaliação de cultivares de milho para o processamento de pamonha. Pesquisa Agropecuária Tropical, 34(1): 39-4, 2004.

ARAÚJO, W. M. C. Da alimentação à gastronomia. Brasília: Editora Universidade de Brasília, 2005.

BARHAM, P. A Ciência da Culinária. São Paulo: Roca, 2002.

BOTELHO, R. B. A. Comercialização e Rotulagem de Produtos Alimentícios Diet e Light no Mercado Varejista de Campinas e Araras. In: V Congresso SBAN, 1999, São Paulo. V Congresso SBAN, 1999.

BOTELHO, R. B. A. Culinária Regional: o Nordeste e a alimentação saudável. Tese (em Doutorado Em Nutrição) - Universidade de Brasília, Brasília, 2006.

BRASIL, Ministério da Saúde. Secretaria de Políticas de Saúde. Coordenação- Geral da Política de Alimentação e Nutrição. Alimentos regionais brasileiros.Brasília: Ministério da Saúde, 2002.

BRASIL, Agência Nacional de Vigilância Sanitária. Disponível em http://www.anvisa.gov.br. Acessado em 22 de fevereiro de 2007. 
CARDOSO, M. J.; CARVALHO, H. W. L.; RIBEIRO, V. Q. Avaliação preliminar de cultivares de milho para produção de espiga verde em sistema agrícola familiar. Revista Ciência Agronômica. Vol. 35, 406-409, 2004.

CARVALHO, A. J. Cozinha típica brasileira: sertaneja e regional. Rio de Janeiro: Ediouro, 1998.

CASCUDO, L. da C. História da Alimentação no Brasil. São Paulo/ Belo Horizonte: Editora USP/ Itatiaia, 2004.

EVANGELISTA, J. Tecnologia de Alimentos.São Paulo: Editora Atheneu, 1998.

FERNANDES, C. Viagem gastronômica através do Brasil. São Paulo: Editora Estúdio Sonia Robatto, 2004.

FREITAS, F. de O. Estudo genético-evolutivo de amostras modernas e arqueológicas de milho (Zea mays, L.) e feijão (Phaseolus vulgaris, L.). Piracicaba, 2001.

FILHO, I. A. P. O Cultivo do milho verde. Brasília: Editora Embrapa, 2003.

FRANCO, G. Tabela de Composição Química de Alimentos. Rio de Janeiro/ São Paulo: Atheneu, 1992.

GLÓRIA, E. C. S. [et al.]. Avaliação proteica de uma nova multimistura com base no milho QPM BR 473. Revista Nutrição. Campinas: n17, p. 379385,jul./set. 2004.

GONSALVES, P. E. Livro dos Alimentos. São Paulo: Editora Martins Fontes, 1992.

GOMENSORO, M. L. Pequeno Dicionário de Gastronomia. Rio de Janeiro: Objetiva, 1999. 
JONES, B. Dicionário Prático de Culinária. São Paulo: Editora Melhoramentos, 1996.

JÚNIOR, O. L. F. G.; DELIZA, R.; BRESSAN-SMITH, R.; PEREIRA, G. P.; CHIQUIERE, T. B. Seleção de genótipos de milho mais promissores para o consumo in natura. Revista Ciência e Tecnologia de Alimentos. v. 26, 0000, Campinas, 2006.

KRAUSE, M. V. Alimentos, nutrição e dietoterapia: um livro texto do cuidado nutricional. São Paulo:Roca, 1991.

LEME, A. C.; SARMENTO, S. B. S. Avaliação do processamento e da qualidade do creme de milho verde (pamonha) produzido no município de Piracicaba -SP. Universidade de São Paulo, São Paulo, 2004.

MINISTÉRIO DA SAÚDE. Alimentação e cultura. Departamento de Nutrição da Faculdade de Ciências da Saúde da Universidade de Brasília (FS/UnB) e Área Técnica de Alimentação e Nutrição do Departamento de Atenção Básica da Secretaria de Política de Saúde do Ministério da Saúde (DAB/SPS/MS), 2004.

ORNELLAS, L. H. Técnica Dietética. Seleção e preparo de alimentos. 7. ed. São Paulo: Atheneu Editora, 2001.

PÉCLAT, G. T.S. C. Hábitos alimentares e a noção simbólica do de comer em Goiás. GUANICUNS: Revista da Faculdade de Educação e Ciências Humanas de Anicuns. FECHA/FEA- Goiás, 02, 211-223, 2005.

PHILIPPI, S. T.; LATTUZA, A. R.; CRUZ, A. T. R.; RIBEIRO, L. C. Pirâmide alimentar adaptada: guia para escolha dos alimentos. Revista de Nutrição. Campinas, v.12, 1, 65-80, 1999.

PHILIPPI, S. T. Nutrição e Técnica Dietética. Barueri, São Paulo: Manole, 2003. 
PONCIANO, N. J.; SOUZA P. M.; REZENDE A. M. Entraves da comercialização à competitividade do milho brasileiro. Revista Paranaense de Desenvolvimento. Curitiba, n. 104, 23-40, 2003.

SCHILLING, M. Qualidade em Nutrição. $2^{a}$ ed. Rio de Janeiro: Varela,1998.

SEBRAE- Agência de Notícias. Em Goiânia tudo acaba em pamonha. Disponível http://www.sebraego.com.br/site/ . Acessado em 11 de novembro de 2006.

SEBRAE- Agência de Notícias. Pamonharias goianas estão de olho na qualidade. Disponível em http://www.sebraego.com.br/sitel. Acessado em 11 de novembro de 2006.

SEBRAE- Agência de Notícias. Empresa familiar investe em produtos da culinária goiana. Disponível em http://www.sebraego.com.br/sitel. Acessado em 11 de novembro de 2006.

TABELA BRASILEIRA DE COMPOSIÇÃO DE ALIMENTOS - TACO/ NEPA Unicamp, 2004. 42p.

UDRY, C. V.; DUARTE, W. (orgs.). Uma história brasileira do milho: o valor dos recursos genéticos. Brasília: Paralelo 15, 2000. 
ANEXOS 


\section{Anexo 1 - Ficha de preparação da Pamonha " de Doce"}

NOME DA PREPARAÇÃO: Pamonha "de Doce"

\begin{tabular}{|c|c|c|c|c|}
\hline INGREDIENTES & $\begin{array}{l}\text { Peso } \\
\text { Bruto }\end{array}$ & $\begin{array}{l}\text { Medida } \\
\text { Caseira }\end{array}$ & FC & Modo de Preparo \\
\hline Milho verde ralado & $1000 \mathrm{~g}$ & $\begin{array}{l}\text { Cerca de } \\
10 \text { espigas }\end{array}$ & & \multirow{9}{*}{$\begin{array}{l}\text { Depois de ralado o milho acrescentar } \\
\text { todos os ingredientes, sendo que óleo } \\
\text { deve ser quente. Envasar a massa em } \\
\text { copinhos feitos com a própria palha do } \\
\text { milho e em seguida colocar recheios como } \\
\text { queijo mussarela em fatias (o mais } \\
\text { tradicional) ou creme de leite ou queijo } \\
\text { ralado. } \\
\text { Em seguida envolver o copinho com outra } \\
\text { palha e amarrar com elástico (ou } \\
\text { barbante) e levar ao fogo para cozinhar } \\
\text { por cerca de } 30 \text { a } 45 \text { minutos ou até a } \\
\text { palha ficar amarelada. } \\
\text { *Obs.: opcionais. Não foram usados para } \\
\text { o cálculo nutricional. }\end{array}$} \\
\hline Açúcar cristal & $300 \mathrm{~g}$ & & & \\
\hline Sal refinado & $3 g$ & $\begin{array}{l}1 / 2 \text { colher } \\
\text { de chá }\end{array}$ & & \\
\hline Óleo de soja & 150ml & 1 copo & & \\
\hline Gordura vegetal & $25 g$ & $\begin{array}{l}1 \text { colher de } \\
\text { sopa cheia }\end{array}$ & & \\
\hline Queijo mussarela & $100 \mathrm{~g}$ & & & \\
\hline Fermento em pó & $3 g$ & $\begin{array}{l}1 / 2 \text { colher } \\
\text { de chá }\end{array}$ & & \\
\hline Creme de leite* & $70 \mathrm{~g}$ & & & \\
\hline Queijo ralado* & $100 \mathrm{~g}$ & $\begin{array}{l}1 \text { xícara de } \\
\text { chá cheia }\end{array}$ & & \\
\hline
\end{tabular}

Rendimento: 10 pamonhas

Peso por porção individual: $150 \mathrm{~g}$

Energia (Tabela TACO e ANVISA): $436 \mathrm{Kcal}$

Proteínas: $5,2 \mathrm{~g}$

Carboidratos: $58,1 \mathrm{~g}$

Lipídios: $21,5 \mathrm{~g}$ 
Anexo 2 - Ficha de preparação da Pamonha " de Sal"

NOME DA PREPARAÇÃO: Pamonha "de Sal"

\begin{tabular}{|c|c|c|c|c|}
\hline INGREDIENTES & $\begin{array}{l}\text { Peso } \\
\text { Bruto }\end{array}$ & $\begin{array}{l}\text { Medida } \\
\text { Caseira }\end{array}$ & FC & Modo de Preparo \\
\hline Milho verde ralado & $1000 \mathrm{~g}$ & $\begin{array}{l}\text { Cerca de } \\
10 \text { espigas }\end{array}$ & & \multirow{9}{*}{$\begin{array}{l}\text { Depois de ralado o milho acrescentar } \\
\text { todos os ingredientes, sendo que óleo } \\
\text { deve ser quente. Envasar a massa em } \\
\text { copinhos feitos com a própria palha do } \\
\text { milho e em seguida colocar recheios } \\
\text { como queijo mussarela em fatias (o mais } \\
\text { tradicional) ou creme de leite ou queijo } \\
\text { ralado. } \\
\text { Em seguida envolver o copinho com outra } \\
\text { palha e amarrar com elástico (ou } \\
\text { barbante) e levar ao fogo para cozinhar } \\
\text { por cerca de } 30 \text { a } 45 \text { minutos ou até a } \\
\text { palha ficar amarelada. } \\
\text { *Obs.: opcionais. Não foram usados para } \\
\text { o cálculo nutricional. }\end{array}$} \\
\hline Açúcar cristal & $25 g$ & $\begin{array}{l}1 \text { colher de } \\
\text { sopa }\end{array}$ & & \\
\hline Sal refinado & $5 g$ & $\begin{array}{l}1 / 2 \quad \text { colher } \\
\text { de chá }\end{array}$ & & \\
\hline Óleo de soja & 150ml & 1 copo & & \\
\hline Gordura vegetal & $25 g$ & $\begin{array}{l}1 \text { colher de } \\
\text { sopa cheia }\end{array}$ & & \\
\hline Queijo mussarela & $100 \mathrm{~g}$ & & & \\
\hline Fermento em pó & $3 g$ & $\begin{array}{l}1 / 2 \text { colher } \\
\text { de chá }\end{array}$ & & \\
\hline Creme de leite * & $70 \mathrm{~g}$ & & & \\
\hline Queijo ralado * & $100 \mathrm{~g}$ & $\begin{array}{l}1 \text { xícara de } \\
\text { chá cheia }\end{array}$ & & \\
\hline
\end{tabular}

Rendimento: 10 pamonhas

Peso por porção individual: $150 \mathrm{~g}$

Energia (Tabela TACO e ANVISA): $330 \mathrm{Kcal}$

Proteínas: $5,2 \mathrm{~g}$

Carboidratos: $30,6 \mathrm{~g}$

Lipídios: 21,5 